\title{
Educational Upward Mobility. Practices of Social Changes--Research on Social Mobility and Educational Inequality
}

\author{
Mei-ling $\operatorname{Lin}^{1}$ \\ ${ }^{1}$ Department of Social Science, National Open University, Taiwan R.O.C. \\ Correspondence: Mei-ling Lin, Department of Social Science, National Open University, Taiwan R.O.C.
}

Received: February 26, 2020

Accepted: March 17, 2020

Available online: March 26, 2020

doi:10.11114/ijsss.v8i3.4789

URL: https://doi.org/10.11114/ijsss.v8i3.4789

\begin{abstract}
Social class is defined by the possession of all forms of economic capital, cultural capital and social capital which together shape the kinds of experience and lifestyles. This process is dubbed symbolic violence by Pierre Bourdieu. Education is crucially linked to assets such as income, occupational position and social prestige. Educational upward mobility requires more than individual effort and intelligence, and sometimes different ingredients, such as specific social conditions. The different dimensions of inequality-income, poverty, social exclusion, education and social mobility - are interconnected. The paper has been inspired by Bourdieu's work on symbolic domination and capitals, and lifestyles. The author identifies a persistence of inequalities among the students due to social reproduction mechanisms: family background and parents' social situation have a substantial influence on the life chances. The empirical data of this study come from a survey in 2019. The paper ends with a summary of findings and conclusions.
\end{abstract}

Keywords: social reproduction, symbolic violence, social mobility, educational inequality, lifestyle

\section{Introduction}

\subsection{Education and Social Changes}

Competition to expand markets and develop skilled workforces defines globalization, and these changes affect schooling (Pasi Sahlberg, 2016; Emmanuel Jean Francois, 2015; Theodora Lightfoot-Rueda and Ruth Lynn Peach, 2015). Education is recognized as a powerful tool for constructing more inclusive national economies (Karen Mundy, Andy Green, Bob Lingard, and Antoni Verger, 2016), and is seen as one way of promoting integrated policies to tackle challenges (Eugenia A. Panitsides, 2015). Those educational changes are seen as a precursor for the social, economic and cultural transformations. Would education be the centerpiece of reducing inequality (Martin Carnoy, 2016)? Education is always not only a process of reproduction but also a process of transformation (Stephen Kemmis and Christine Edwards-Groves, 2018). This global competition for talent, particularly in the STEM (Science, Technology, Engineering and Mathematics) fields, has implications for the educational and employment aspirations of youth as a promising avenue for income (Robin R. Marsh and Ruth Uwaifo Oyelere, 2018).

Globalization has increased pressure on states to expand their higher educational systems (Martin Carnoy, 2016). The stress on the employability of their graduates has challenged colleges to evaluate the fit between education and workplace (Cheryl A. Matherly and Martin J. Tillman, 2015). Higher education institutions are under pressure to show their societal relevance that they are the instrument for reaching certain societal agendas like social mobility and economic development (Rómulo Pinheiro, Gerald Wangenge-Ouma, Elizabeth Balbachevsky and Yuzhuo Cai, 2015). Students from different social class backgrounds make different decisions regarding educational transitions. This has consequences for how social inequality is reproduced at education. The parents' economic capital explains most of the social class effect (Liza Reisel, 2013). Social stratification researches should include consideration about the impact of higher education on the public's acceptance of colleges (David Post, 2010).

\subsection{Educational Upward Mobility}

Educational upward mobility requires more than individual talent and effort, and sometimes different ingredients such as the education system (Antonia Kupfer, 2015; Sophie Hahn, 2016). Tepecik (2011) conducted a study on socially upwardly mobile children from ethnic minorities and reported that families had a positive attitude toward education (Antonia Kupfer, 2015). Siraj-Blatchford (2010) conducted case studies of underprivileged families from ethnic 
minorities. She speaks of the parents' cultivation of children toward social upward mobility (Antonia Kupfer, 2015). Blau and Duncan realized that education assumes the significance for social status from fathers to sons in particular (Antonia Kupfer, 2015). Collins (1979) offered the view that education is a cultural basis that shapes positions and careers (Antonia Kupfer, 2015). Goodwin (2002) supported the importance of resilience for educational success among disadvantaged students (Antonia Kupfer, 2015). Breen and Jonsson believed that the change in hiring practices was based on educational expansion. These findings point to the importance of policies that reduce social inequality in education as a prerequisite for social mobility (Antonia Kupfer, 2015).

The overview of researches on societal influences on upward mobility revealed a failure to consider cultural influences, changing attitudes and lifestyles. My analysis of the life histories of educationally upwardly mobile people, 236 college students responses to the questionnaire "Lifestyles and Social Stratification (LSS): An Explorative Study of Taiwan", is aware of such cultural dimensions and adds them to enhance the understanding of the societal circumstances that influence social upward mobility. This study is concerned with the experience of upward mobility among working-class members and questions about how to increase their participation in higher education. One important research question is whether the opening up of higher levels of education to all has led to more equal chances between social classes. Due to the important role of education in mediating class origins and destinations, this study concentrates on the link between social origin and educational inequality (Sophie Hahn, 2016).

\subsection{Symbolic Domination and Capitals}

For the ideas of Pierre Bourdieu, social class is defined by the possession of all forms of economic capital, cultural capital and social capital (Will Atkinson, Steven Roberts and Mike Savage, 2013; Liza Reisel, 2013). Bourdieu's works on symbolic domination and capitals, and lifestyles and tastes have explored how class affects people (Andrew Sayer, 2013). The class structure reproduces itself through the transmission of economic, social, and cultural capital from parents to their children that is dubbed the cultural reproduction theory (Sophie Hahn, 2016). The class-specificity of habitus reveals the educational pathways to higher degrees differ among working, middle, and upper-class members (Antonia Kupfer, 2015). People worry about rising inequality, weaker social protection and the divergence of income levels (Michael Dauderstädt, 2018). We have seen a growth of sociological studies of class - studies of economic inequalities, differences in life chances, and the formation of tastes and lifestyles (Andrew Sayer, 2013; Will Atkinson, Steven Roberts and Mike Savage, 2013). Concerns with the economic and symbolic violence inflicted on and through education and family life, including the stratified impact of the recession and austerity (Will Atkinson, Steven Roberts and Mike Savage, 2013).

\subsection{Inequality}

The different dimensions of inequality - income, poverty, social exclusion, education and social mobility-are interconnected (Renato Miguel Carmo, Cédric Rio, and Márton Medgyesi, 2018). Besides these transformations in the labour markets, demographic and societal changes and the decrease in redistribution constitute the drivers of inequality (Guillaume Cohen and Maxime Ladaique, 2018). Opportunities of young adults to cope with the consequences of the economic recession varied according to family background (Márton Medgyesi, 2018). These inequalities are associated with negative social outcomes (Lyn Tett, 2018), and the risks include a rise in unemployment and growth in precarious work (Renato Miguel Carmo and Ana Rita Matias, 2018).

The education systems have been to grow rapidly, with many making the shift from elite to mass higher education systems (Sam Sellar and Trevor Gale, 2016). In a meritocratic society, educational inequalities are legitimate if they are linked to a person's level of ability and effort (Sophie Hahn, 2016). Yet behind this picture lies a reality of contradiction (Harriet Bradley and Nicola Ingram, 2013). Due to the increasing role of education in mediating class origins and destinations, education should have become more affordable for the lower classes, and class differences should decline (Sophie Hahn, 2016). Class inequalities in education are not just about what students bring to the classroom; they are also about the unequal educations students receive (Diane Reay, 2013). Following Breen and Goldthorpe, social inequality in education should have increased more for women than for men (Sophie Hahn, 2016). Raftery and Hout (1993) found that the educational inequalities decrease during a period of educational expansion. It requires analyses of the differences in educational chances to be found between classes of social origin (Sophie Hahn, 2016).

Increasing income inequality particularly since the economic crisis of 1997 has called attention to the issue of growing educational inequality. The author examines social reproduction mechanisms and compares the social situation of people in Taiwan: family background and parents' social situation and educational level have an influence on the life chances of the respondents. Using nationally representative data for the cohorts (2019, March) of college students from "Lifestyles and Social Stratification: An Explorative Study of Taiwan (LSS)", this study examines trends in the relationship between lifestyles and social stratification. The data demonstrate that the influence of socioeconomic background on student achievement has increased, offering evidence of growing educational inequality in Taiwan. The 
focus on working-class people captures the political, economical, and cultural structures that supported their educational upward mobility.

\subsection{Higher Education and Entrepreneurship}

Countries compete with one another to attract the best minds to fuel science and technology-driven industries (Robin R. Marsh and Ruth Uwaifo Oyelere, 2018). The knowledge mindset becomes important to help the individual "navigate today's uncertainties and tomorrow's unknown developments" (Daniele Morselli, 2015). Creative practices have gained a new significance as contemporary labour (Stephanie Taylor, 2018). Society is to be built out of creative and entrepreneurial education-produced innovations (Francisco O. Ramirez, John W. Meyer, and Julia Lerch, 2016). Higher education institutions have a decisive role to play, particularly in promoting employability and preparing a skilled workforce (Eugenia A. Panitsides, 2015). Education might be a critical investment in economic development (Peter Easton and Malaika Samples, 2015). Higher education institutions have been subjected to many reforms, encouraged by the emergence of the knowledge society and economic crises (Bruno Broucker and Kurt De Wit, 2015). The lifelong learning for all emphasized universal access to learning opportunities over the entire lifespan (Richard Desjardins, 2018).

Both economic and educational resources are determinant factors in people's living conditions and societal development (António Firmino da Costa, Rosário Mauritti, Susana da Cruz Martins, Nuno Nunes, and Ana Lúcia Romão, 2018). The paper examines the relationships between education and society through concepts related to social change, social mobility and educational inequality. Taiwan has developed an integrated learning society that has restructured the educational system and placed lifelong learning at the centre of the educational and economic development. In response to rapid globalization and the knowledge-based era, Taiwan realizes the vision of developing an open and lifelong learning society. Such is the landscape of political-economic-symbolic power characterizing contemporary Taiwan. The author looks at the activities in a range of work and education, and explores the coping strategies adopted by people to manage difficulties and life circumstances. Using qualitative and quantitative research made it possible to link big picture social and educational change and social life.

\subsection{Theoretical Foundations}

\subsubsection{Education and Social Change}

Education is the social institution responsible for the systematic transmission of knowledge, and has been viewed as a socialization experience (Emmanuel Jean Francois, 2015; John McAdams, 2015). Human factor is fundamental to economic activity, competitiveness and social advance (Richard Desjardins, 2018; Emmanuel Jean Francois, 2015). We use terms such as "education for human capital" to underlie discussions concerning education (Theodora Lightfoot-Rueda and Ruth Lynn Peach, 2015; Anastasia Liasidou, 2015). Education increases individuals' productivity, and emphasizes the investment value of education as a means for achieving two central goals: economic growth and poverty reduction (Cheryl A. Matherly and Martin J. Tillman, 2015; Richard Desjardins, 2018; Xavier Bonal, 2016). Social reproduction continues to operate, but their trajectories remain influenced by the class and gender (Robin Simmons, Ron Thompson and Lisa Russell, 2014). Education is linked to assets such as income and occupational position that are determinants of individual life chances (Sophie Hahn, 2016).

Education has become the important mechanism of the status transmission between the generations (Steffen Hillmert, 2013). Persons from higher social origin gain higher levels of education and, thus, higher occupational and social positions (Sophie Hahn, 2016). The degree of the structuration of life courses by social origin and education has increased. Critical theorists have focused on how education is implicated in the reproduction of inequality (Robin Simmons, Ron Thompson and Lisa Russell, 2014). Schools allow students to change their locations within the class structure of society (Stephen Kemmis and Christine Edwards-Groves, 2018). Higher education as human capital, as economic progress and as equality of opportunity, has a great role in making society (Simon Marginson, 2016A), and is seen as a means of developing a career and getting secure employment (Ann-Marie Bathmaker, Nicola Ingram, Jessie Abrahams, Anthony Hoare, Richard Waller and Harriet Bradley, 2016). Higher education is an instrument of social justice and social order, especially through the sanctioning of upward mobility (Simon Marginson, 2016B). Employability has become a desirable outcome for higher education. The task of government is to encourage growth in the stock of human capital (Cheryl A. Matherly and Martin J. Tillman, 2015).

\subsubsection{Educational Upward Mobility}

Analyses of intergenerational social mobility and reproduction have stressed the importance of the family of origin for the transmission of social inequality (Steffen Hillmert, 2013). The socioeconomic status of the family exerts a substantial influence on the educational outcomes of their children (Gianluca Manzo, 2013). Blau and Duncan realized that superior family origins increase a son's chances of attaining superior occupational status. The norm makes 
education important to status (Antonia Kupfer, 2015).Collins (1979) asserted that technological development requires more highly educated people (Antonia Kupfer, 2015). Education is linked to assets such as income, occupational position and social prestige that are determinants of individual life chances (Sophie Hahn, 2016). The term social mobility refers to the movement of individuals or groups that can be measured by changes in status related to cultural capital, social capital, symbolic capital, or economic capital (Emmanuel Jean Francois, 2015).

Schools enable and impede social upward mobility. Turner called the predominant norm of upward mobility in the United States "contest mobility", in which elite status is the prize in an open contest. He called the predominant norm in Great Britain "sponsored mobility", in which elite status cannot be taken by any amount of effort (Antonia Kupfer, 2015). The social mobility perspective on educational inequalities is a particular way of looking at differences in educational outcomes (Sophie Hahn, 2016). Mobility in a society can occur because of two factors: firstly, the society may provide more opportunities to the future generation than the present one, which is called "structural mobility"; secondly, there may occur social churning whereby some people improving upon their parental background at the cost of some people going down, which is called "exchange mobility" (Rajarshi Majumder, 2013).

\subsubsection{Symbolic Domination and Capitals}

Capital refers to the resources people obtain, described as economic, cultural, social, and symbolic capital, which influence their positions (Antonia Kupfer, 2015). Pierre Bourdieu argued three forms of capital: financial, cultural and social that this process is dubbed symbolic violence (Liza Reisel, 2013; Will Atkinson, Steven Roberts and Mike Savage, 2013; Robin Simmons, Ron Thompson and Lisa Russell, 2014; Antonia Kupfer, 2015). Cultural capital makes a substantial contribution to the inter-generational reproduction of class positions (Ann-Marie Bathmaker, Nicola Ingram, Jessie Abrahams, Anthony Hoare, Richard Waller and Harriet Bradley, 2016). Collins emphasizes that the usefulness of different kinds of resources changes according to social context (Liza Reisel, 2013).

Classes are defined by their position in the economic structure, and develop distinctive ideologies reflecting their interests (John McAdams, 2015). Classes are characterized by the shape of their particular distributions of capital, and class struggle may be expressed in symbolic form (Robin Simmons, Ron Thompson and Lisa Russell, 2014). Class is not just about life chances and equality of opportunity, but about self-worth and suffering (Will Atkinson, Steven Roberts and Mike Savage, 2013). Bourdieu postulates the social mechanisms to explain how culture legitimates and reproduces class inequality (Gartman David, 2013). Bourdieu recognized that markers of social class—cultural tastes, social networks, etc.- -are transmitted within classes through both schooling and cultural discrimination (Katja M. Guenther, Matthew C. Mahutga, and Panu Suppatkul, 2016). This direction in class analysis is in the economic inequalities, and differences in life chances (Will Atkinson, Steven Roberts and Mike Savage, 2013). Social class or socioeconomic status, is a key predictor of life chances, and the study of mobility is the core area in the stratification studies (Katja M. Guenther, Matthew C. Mahutga, and Panu Suppatkul, 2016).

Bourdieu conceptualized social space as two dimensions: social position and lifestyle. People create their social positions, based on distinct lifestyles (Antonia Kupfer, 2015). Bourdieu determines social positions, using economic and cultural capital as the main determinants of the social space (Gunn Elisabeth Birkelund and Yannick Lemel, 2013). Bourdieu defines habitus as "systems of durable, transposable dispositions" that enables the analysis of working or middle-class-specific behavior (Antonia Kupfer, 2015). There is an inequality of chances that guarantees the reproduction of an unequal society (Emmanuel Jean Francois, 2015). Social class differences in educational achievement are not the differences in values, but arise from the educational opportunities (Robin Simmons, Ron Thompson and Lisa Russell, 2014). The educational systems are crucial that Bourdieu views education as an instance of social norms and values authorizing social hierarchies (Antonia Kupfer, 2015). The term "stratification" is used to describe explanations for unequal distributions that focus upon class (Katja M. Guenther, Matthew C. Mahutga, and Panu Suppatkul, 2016). Social stratification analysis comprises a range of topics, including social mobility, economic inequality, educational attainment, the stratification of lifestyles and attitudes (Gunn Elisabeth Birkelund, 2013).

\subsubsection{Inequality}

The different dimensions of inequality, income, poverty, social exclusion, education and social mobility, are interconnected (Renato Miguel Carmo, Cédric Rio, and Márton Medgyesi, 2018). Social exclusion and poverty highlight one particular aspect of social inequality (Orsolya Lelkes and Katrin Gasior, 2018). Bourdieu (1979) formalises resource inequality in terms of unequal distributions of economic, cultural and social capital (Renato Miguel Carmo and Ana Rita Matias, 2018). Children are differently equipped for educational careers respective to their social origin (Sophie Hahn, 2016). Economic inequality is tied to the variation that is captured by social class and occupational prestige (Carl le Grand and Michael Tåhlin, 2013). Family or father's income is of importance for children's education since education is by far the strongest influence on income (Gary N. Marks 2013:347; Márton Medgyesi, 2018). Inequality can be conceptualized by the equality of opportunity where the focus is on the achievement 
of equality of access to education (Lyn Tett, 2018). Education systems can be seen as products of inequality (Antonia Kupfer, 2015).

\subsection{Aims \& Underlying Assumptions}

Educational upward mobility is a phenomenon of social change that relates to the structure of specific social contexts. Three categories of factors can be identified: individual motives, educational systems, and societal structures. The author will clarify this stream of research by demonstrating how students' educational upward mobility is linked to their families' motivating socialization, and cultural and political openness to working-class participation in higher education. While providing a survey of changing higher education policy contexts, the paper draws on empirical research projects examining the policy of social mobility and educational inequality in Taiwan higher education in 2019. The data generated from this project provide an important empirical backdrop to our argument. On the basis of these data, the author hope to develop a new model of the social mobility and educational inequality in Taiwan.

To draw objective conclusions from these factors, a theoretical framework is needed. The empirical data of this study come from 236 participants in the National Open University, Kaohsiung Learning Centers, Taiwan. Survey questionnaire "Lifestyles and Social Stratification (LSS): An Explorative Study of Taiwan" was conducted until March 2019. The survey aimed to develop a new model of social class, combining measures of economic, cultural and social capital in order to map contemporary class divisions in Taiwan. We highlight the continuing salience of class to our understanding of inequalities and mobility in Taiwan. The author applies the Analysis of Variance (ANOVA) and Multivariate Regression methods where the student's characteristics have been regressed on parental characteristics along with other explanatory variables. The data show the impact of social contexts on the educational upward mobility of participants. Their life histories demonstrate how social change takes place, how certain social structures create perceptions that lead to certain actions and lifestyles that differ from those of their parents and move them from the working class toward the middle or upper class. The paper ends with a summary of findings and conclusions, reflecting on the transformative experience of higher education and the possibilities for social mobility, and ending with implications for social policies on widening participation of higher education.

As indicators of social stratification, we use education level, household income, and occupational status; and to measure lifestyles, we use data from a surveys on lifestyles and cultural consumption. We would expect to find common empirical patterns that may be of relevance to the way we conceptualize lifestyles and social stratification. Given the economic, political and cultural differences, we find it interesting exploring the patterns of social stratification and people's lifestyles in Taiwan. The purposes of this paper are two: firstly, to test attitudes about lifestyles and social stratification with survey data, and secondly, to interpret the relationship between social mobility and educational inequality. We observe how the participants' experience of higher education and the resources they brought into and acquired within higher education were shaped by their social-class backgrounds. We hope to understand the obstacles as well as the opportunities that might be placed in the way of people from class backgrounds in not only accessing but also reaping the benefits of higher education. This would inform the aims of assessing the role of higher education in helping to build a fairer and more open society.

\section{Method}

One way of assessing inequalities in learning opportunities is to examine the extent to which socioeconomic background relates to students and their school performance. If student and school performance were to strongly depend on socioeconomic background, large inequalities in the distribution of learning opportunities might remain. We examine the trends in the relationship between socioeconomic background and student achievement in Taiwan from the trends in "Lifestyles and Social Stratification: An Explorative Study of Taiwan (LSS)" database. The National Open University, Taiwan supports working-class inclusion and plays a crucial role in the life of one educationally upwardly mobile subject.

The random sample is representative of individuals aged 18 years or older who are the students of the National Open University, Taiwan. We aim to cover a range of department, and recruit 236 students for a survey, drawn from 6 department / graduate institute and degree: liberal arts, social science, living sciences, business, public administration, and management and information. Focusing on these subjects presented us with something of a challenge in identifying enough participants from a working-class background. Most of our surveys contain a Likert five-point scale dealing with respondents' attitudes toward the general proposition. We analysed our data using the quantitative data analysis software program SPSS. The response rate is nearly $90 \%$. To demonstrate clearly what was decisive for educational upward mobility, the author will focus on the parents' backgrounds, materially secure living conditions, and subjects' lifestyles. The living conditions and lifestyles of all the subjects are very diverse, ranging from security funded by decent civil service employment to precarious, below-poverty-threshold conditions. For the demographic characteristics of respondents, see Table 1. For the subscales and items about LSS Questionnaires, see Table 2. 
For Framework of Empirical Study about the survey LSS, see Figure 1. The commonly used components are income, education and occupational prestige. The concept of social mobility is based on the assumption that educational outcomes, occupational positions, and social prestige can be categorized hierarchically. Furthermore, social mobility invokes the notion that the parents' status defines a social origin whereas the achieved status is the point of destination. The quantitative techniques can discover the individual motives embedded in social contexts for analysis. We have used statistical techniques to control for a variety of extraneous variables, in order to estimate the independent effect of education on worldview. Weber identified social stratification as a multidimensional concept, including social class, status, and power (Gunn Elisabeth Birkelund and Yannick Lemel, 2013). In order to explore social inequality, the author includes the set of socio-demographic characteristics, such as gender, education, income and occupation. Survey data on a wide variety of attitudes will allow us to identify individuals holding the worldviews of the working class or middle class, and new class attitudes. The independent predictors in the models are gender, department / graduate institute, education level, occupation status, and household income. The term working class is used here to describe people whose parents are included in the categories of the socio-economic classification, including agriculture, industry and commerce, housekeeper or unemployment, death or retirement.

Table 1. Demographic characteristics of respondents about "Lifestyles and Social Stratification: An Explorative Study of Taiwan"

\begin{tabular}{|c|c|c|c|c|c|}
\hline independent variables & $\begin{array}{c}\text { number } \\
\mathrm{N}\end{array}$ & $\begin{array}{c}\text { percent } \\
\%\end{array}$ & independent variables & $\begin{array}{c}\text { number } \\
\mathrm{N}\end{array}$ & $\begin{array}{c}\text { percent } \\
\%\end{array}$ \\
\hline 1gender & 236 & 100.0 & $\begin{array}{l}\text { 4main occupation that the main } \\
\text { source of the economy at your } \\
\text { home }\end{array}$ & 236 & 100.0 \\
\hline (1)male & 60 & 25.4 & $\begin{array}{c}\text { (1)military, police and civil } \\
\text { service }\end{array}$ & 54 & 22.9 \\
\hline (2)female & 176 & 74.6 & $\begin{array}{l}\text { (2)agriculture, industry and } \\
\text { commerce }\end{array}$ & 157 & 66.5 \\
\hline $\begin{array}{c}\text { 2Department / Graduate Institute and } \\
\text { Degree }\end{array}$ & 236 & 100.0 & $\begin{array}{c}\text { (3)housekeeper } \\
\text { unemployment }\end{array}$ & 17 & 7.2 \\
\hline (1)Department of Liberal Arts & 28 & 11.9 & (4)death or retirement & 8 & 3.4 \\
\hline (2)Department of Social Science & 82 & 34.7 & $\begin{array}{l}\text { 5average monthly household } \\
\text { income }\end{array}$ & 236 & 100.0 \\
\hline (3)Department of Living Sciences & 74 & 31.4 & $\begin{array}{l}\text { (1) less than } 30 \text { thousand } \\
\text { (\$NTD) }\end{array}$ & 41 & 17.4 \\
\hline (4)Department of Business & 16 & 6.8 & (2) between 30 and 60 thousand & 101 & 42.8 \\
\hline (5)Department of Public Administration & 24 & 10.2 & (3) between 60 and 90 thousand & 59 & 25.0 \\
\hline $\begin{array}{l}\text { (6)Department of Management and } \\
\text { Information }\end{array}$ & 12 & 5.1 & (4) more than 90 thousand & 35 & 14.8 \\
\hline $\begin{array}{l}\text { 3highest level of education that the main } \\
\text { source of the economy at your home }\end{array}$ & 236 & 100.0 & & & \\
\hline (1)some and completed junior high school & 9 & 3.8 & & & \\
\hline (2) some and completed high school & 79 & 33.5 & & & \\
\hline (3)some and completed college & 128 & 54.2 & & & \\
\hline (4)some and completed graduate & 20 & 8.5 & & & \\
\hline
\end{tabular}

Table 2. Subscales and Items about "Lifestyles and Social Stratification: An Explorative Study of Taiwan"

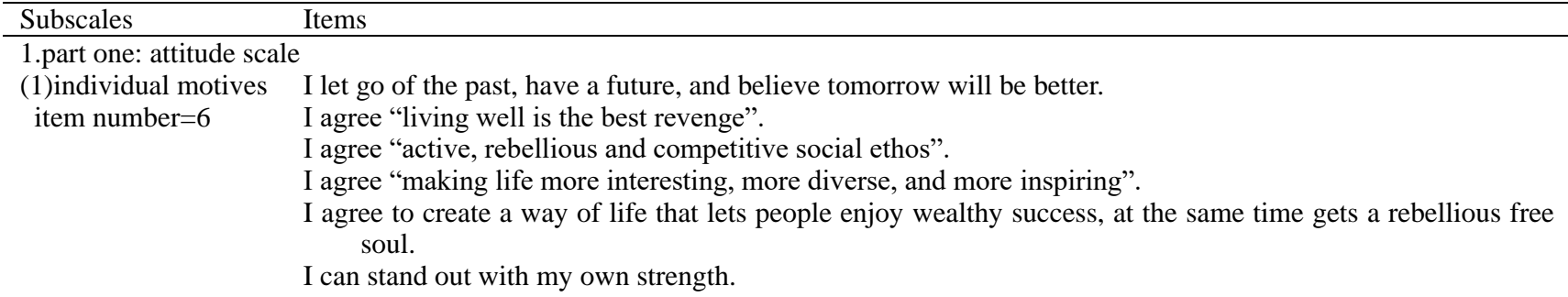

(2)educational systems item number $=6$

Education is considered vital for the formation of a skilled and knowledge-able pool of workers. The university is understood as saving the working-class subject from me and this is achieved by transforming me into more middle-class versions through the provision of forms of capital.

The mass expansion of higher education holds out the promise of opening up access to working class and other disadvantaged groups, who live at a time when knowledge is seen as the key to competing for economic prosperity. 
(3) societal structures item number $=6$
Getting a good education makes me more socially competitive.

As long as I am in the education system do not become aware of the inequalities and processes of exclusion in the wider society and consequently have an optimistic outlook on life.

Creativity and knowledge are as important as natural resources and money capital for the economic success.

Entrepreneurship is able to reverse and revive the low-pay.

Entrepreneurship have a good chance to reach life autonomy or freedom of wealth.

My lifelong-income would be better than my parents'.

My standard-of-living in the future or after retirement would be better than my parents'.

I have a job and express the high levels of civic engagement.

When I am pursuing a creative vision, I can just make money.

2.part two : multiple regression analysis

item number=1 I believe that society is meritocratic, and that I can shape my own fate and that political engagement therefore makes sense.

3.part three : multiple-choice question

item number=3 Family economic conditions adversely affect my ability to achieve a higher degree, also adversely affecting my employment.

My income is not comparable to others, less able to maintain a life comparable to others, and more alienated from society.

Having a college degree does not bring too much money or obvious life change.

4.part four : rank order (priorities)

item number $=2 \quad$ 1Important social issues

(1) people's livelihood and economy

(2) education

(3) food safety

(4) labor rights

(5) environmental protection (including air pollution)

(6) elderly or disadvantaged care

(7) inclusion of immigrant resident

(8) drug abuse and crime

(9) medical

2Definition of success in life

(1) happy family

(2) self, individualism, freedom

(3) make more money, keep pace with the rich

(4) social impact

(5) high socioeconomic status and occupation

(6) healthy

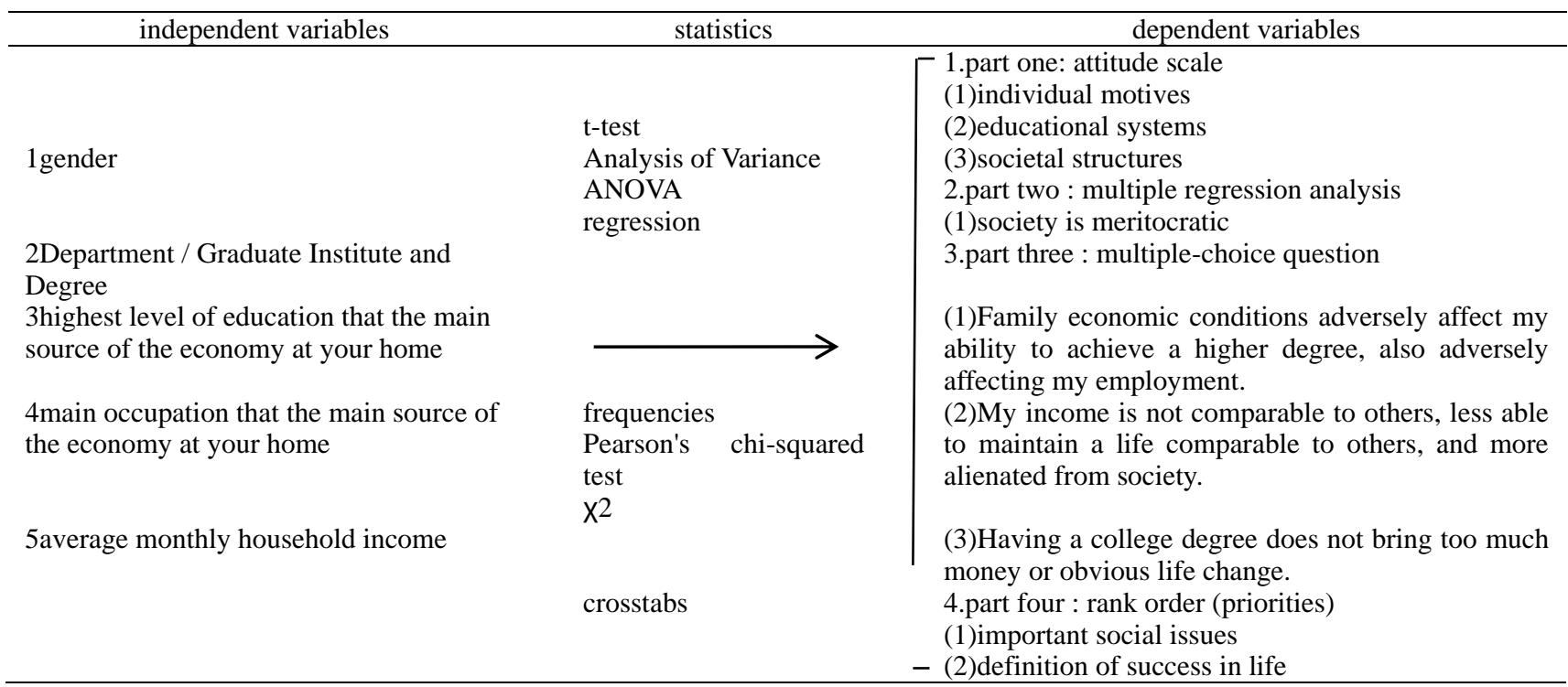

Figure 1. Framework of Empirical Study about "Lifestyles and Social Stratification: An Explorative Study of Taiwan" 


\section{Results}

We find a pattern describing the manifest variables - education, household income, and occupational status. All three variables have positive loadings on the dimensions: societal structures, educational systems and individual motives. We have generated a social space, using the three manifest stratification variables, and we will expect that such a social space will appear in Taiwan where the stratification variables are associated.

\subsection{Societal Structures}

College students in these aspects of gender, department, education, occupation and income, pose no significant differences in the factor of "societal structures", including the aspects of "Entrepreneurship is able to reverse and revive the low-pay", "Entrepreneurship have a good chance to reach life autonomy or freedom of wealth","My lifelong-income would be better than my parents",, "My standard-of-living in the future or after retirement would be better than my parents",, "I have a job and express the high levels of civic engagement", "When I am pursuing a creative vision, I can just make money.", which is shown in Table 3. In these aspects, the female (mean=22.04) do better than the male $($ mean=21.93) $(\mathrm{t}=-.185, \mathrm{p}>.05)$; students apply for the department "Public Administration" (mean=23.42) do better than those "Social Science" (mean=21.79) and those "Living Science" (mean=21.69) $(F=1.467, p>.05)$; householders with junior high school and high school (mean=22.27) as highest level of education outdo those with college and graduate $($ mean=21.86) $(\mathrm{t}=.822, \mathrm{p}>.05)$; householders with housekeeper, unemployment, death or retirement (mean=22.72) as occupation outdo those with agriculture, industry and commerce (mean=22.07) and those with military, police and civil service (mean=21.52) $(\mathrm{F}=.957, \mathrm{p}>.05)$; household income more than 90 thousand (mean=22.46) outperform those less than 30 thousand (mean=21.71), those between NTD 30 and 60 thousand $($ mean $=21.88)$ and those between NTD\$ 60 and 90 thousand $($ mean=22.19) $(\mathrm{F}=.344, \mathrm{p}>.05)$.

Table 3. Abstract: Mean, SD, t-test, ANOVA of empirical study about factor "societal structures"

\begin{tabular}{|c|c|c|c|c|c|c|c|c|c|c|c|}
\hline \multirow[t]{2}{*}{$\begin{array}{l}\text { independent } \\
\text { variables }\end{array}$} & \multirow[t]{2}{*}{$\begin{array}{l}\text { number } \\
\mathrm{N}\end{array}$} & \multirow[t]{2}{*}{$\begin{array}{l}\text { Mean } \\
\text { M }\end{array}$} & \multirow[t]{2}{*}{ SD } & \multicolumn{3}{|c|}{$\begin{array}{l}\text { SS(sum of squares of deviation } \\
\text { from mean) }\end{array}$} & \multicolumn{2}{|c|}{ MS(mean square) } & \multirow[t]{2}{*}{$\mathrm{F}$} & \multirow[t]{2}{*}{$\mathrm{t}$} & \multirow[t]{2}{*}{$\begin{array}{l}\text { post-hoc test } \\
\text { Scheffe }\end{array}$} \\
\hline & & & & $\begin{array}{l}\text { between } \\
\text { groups }\end{array}$ & $\begin{array}{l}\text { within } \\
\text { groups }\end{array}$ & total & $\begin{array}{l}\text { between } \\
\text { groups }\end{array}$ & $\begin{array}{l}\text { within } \\
\text { groups }\end{array}$ & & & \\
\hline 1gender & 236 & & & & & & & & & -.185 & \\
\hline (1)male G1 & 60 & 21.93 & 3.92 & & & & & & & & \\
\hline (2)female G2 & 176 & 22.04 & 3.63 & & & & & & & & \\
\hline 2department & 236 & 22.01 & 3.70 & 79.69 & 3137.27 & 3216.96 & 19.92 & 13.58 & 1.467 & & \\
\hline $\begin{array}{l}\text { (1)Liberal Arts } \\
\text { G1 }\end{array}$ & 28 & 22.75 & 3.42 & & & & & & & & \\
\hline $\begin{array}{l}\text { (2)Social } \\
\text { Science G2 }\end{array}$ & 82 & 21.79 & 3.75 & & & & & & & & \\
\hline $\begin{array}{l}\text { (3)Living } \\
\text { Sciences G3 }\end{array}$ & 74 & 21.69 & 3.88 & & & & & & & & \\
\hline $\begin{array}{l}\text { (4)Business, } \\
\text { Management } \\
\text { and }\end{array}$ & 28 & 21.57 & 3.79 & & & & & & & & \\
\hline $\begin{array}{l}\text { Information G4 } \\
\text { (5)Public }\end{array}$ & 24 & 23.42 & 2.92 & & & & & & & & \\
\hline $\begin{array}{l}\text { Administration } \\
\text { G5 }\end{array}$ & & & & & & & & & & & \\
\hline 3education & 236 & & & & & & & & & .822 & \\
\hline $\begin{array}{l}\text { (1)junior high } \\
\text { school, and } \\
\text { high schoolG1 }\end{array}$ & 88 & 22.27 & 3.81 & & & & & & & & \\
\hline $\begin{array}{l}\text { (2) college and } \\
\text { graduate G2 }\end{array}$ & 148 & 21.86 & 3.64 & & & & & & & & \\
\hline 4occupation & 236 & 22.01 & 3.70 & 26.21 & 3190.75 & 3216.96 & 13.11 & 13.69 & .957 & & \\
\hline $\begin{array}{l}\text { (1)military, } \\
\text { police and civil } \\
\text { service G1 }\end{array}$ & 54 & 21.52 & 4.59 & & & & & & & & \\
\hline $\begin{array}{l}\text { (2)agriculture, } \\
\text { industry and } \\
\text { commerce G2 }\end{array}$ & 157 & 22.07 & 3.51 & & & & & & & & \\
\hline $\begin{array}{l}\text { (3)housekeeper, } \\
\text { unemployment, } \\
\text { death or } \\
\text { retirement G3 }\end{array}$ & 25 & 22.72 & 2.51 & & & & & & & & \\
\hline 5income(NTD) & 236 & 22.01 & 3.70 & 14.27 & 3202.70 & 3216.96 & 4.76 & 13.81 & .344 & & \\
\hline $\begin{array}{l}\text { (1) less than } 30 \\
\text { thousand G1 }\end{array}$ & 41 & 21.71 & 4.09 & & & & & & & & \\
\hline (2) between 30 & 101 & 21.88 & 3.66 & & & & & & & & \\
\hline
\end{tabular}


and 60

thousand $\mathrm{G} 2$

(3) between $60 \quad 59 \quad 22.19 \quad 4.05$

and 90

thousand G3

(4) more than $\quad 35 \quad 22.46 \quad 2.65$

90 thousand G4

$* \mathrm{p}<.05 \quad * * \mathrm{p}<.01 \quad * * * \mathrm{p}<.001$

For "I believe that society is meritocratic, and that I can shape my own fate and that political engagement therefore makes sense", factors "societal structures" and "individual motives" are both the significant predictors but factor "educational systems" does not have the significant explanatory power, which is shown in Table 4. By the standardized regression equation, we can understand the standardized coefficients (Beta, $\beta$ ) as the follows: factor "societal structures" ( $\beta=0.493, p<.001)$, factor "individual motives" $(\beta=0.159, p<.05)$, and factor "educational systems" ( $\beta=0.104, p$ $>.05)$. The priority of predictors on "society is meritocratic" is as follows: "societal structures", "individual motives" and "educational systems" . The more student score on the factor "societal structures", the more item "society is meritocratic" score. For example, if student score on the factor "societal structures" adds 10, accordingly, the score on item "society is meritocratic" would add 4.93; if student score on the factor "individual motives" adds 10, accordingly, the score on item "society is meritocratic" would just add 1.59; if student score on the factor "educational systems" adds 10 , accordingly, the score on item "society is meritocratic" would only add 1.04. Educational upward mobility is a phenomenon of social change that is embedded in changing social structures, but the factor "educational systems" is least valued. Schools enable and impede social upward mobility. Standardized regression equation

$$
\mathrm{Y}_{\text {society is meritocratic }}=0.159 \mathrm{x} \text { individual motives }+0.104 \mathrm{x} \text { educational systems }+0.493 \mathrm{x} \text { societal structures }
$$

Table 4. Multiple regression analysis: factors "individual motives", "educational systems" and "societal structures" predict "I believe that society is meritocratic, and that I can shape my own fate and that political engagement therefore makes sense"

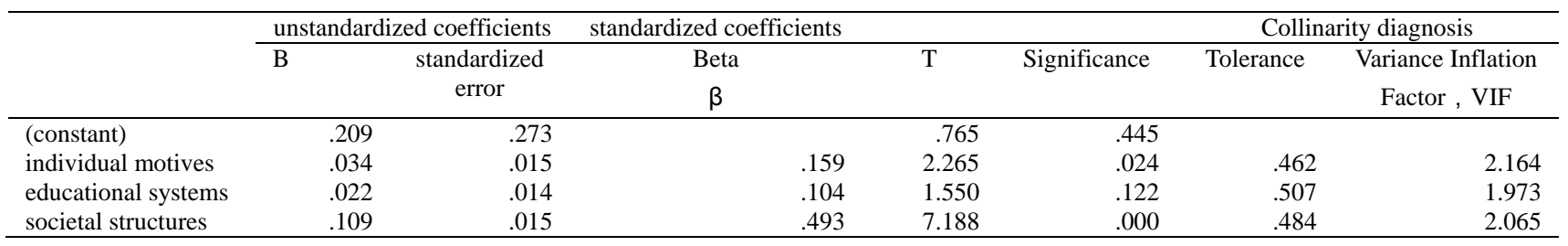

$* \mathrm{p}<.05 \quad * * \mathrm{p}<.01 \quad * * * \mathrm{p}<.001$

For "Family economic conditions adversely affect my ability to achieve a higher degree, also adversely affecting my employment", college students choose "no"(51.3\%) more than "yes"(48.7\%), which is shown in Table 5. In these aspects, $56.7 \%$ of the male prefer to choose "yes" and $54.0 \%$ of the female prefer to choose "no" $(\chi 2=2.029, \mathrm{p}>.05)$; $63.4 \%$ of students apply for the department "Social Science" prefer to choose "no", $52.7 \%$ of students apply for the department "Living Sciences" prefer to choose "yes", 53.6\% of students apply for the department "Business, Management and Information" prefer to choose "yes", $70.8 \%$ of students apply for the department "Public Administration" prefer to choose "yes" $(\chi 2=10.282, \mathrm{p}<.05) ; 52.3 \%$ of householders with junior high school and high school as highest level of education prefer to choose "yes" and 53.4\% those with college and graduate prefer to choose "no" $(\chi 2=.705, \mathrm{p}>.05) ; 53.7 \%$ of householders with military, police and civil service as occupation prefer to choose "yes", $54.1 \%$ of those with agriculture, industry and commerce prefer to choose "no", and $56.0 \%$ of those with housekeeper, unemployment, death or retirement prefer to choose "yes" $(\chi 2=1.581, p>.05) ; 56.1$ of household income less than 30 thousand prefer to choose "yes", 50.5 of those between NTD\$ 30 and 60 thousand prefer to choose "yes", $59.3 \%$ of those between NTD $\$ 60$ and 90 thousand prefer to choose "no", and 51.4\% of those with more than 90 thousand prefer to choose "no" $(\chi 2=2.548, \mathrm{p}>.05)$. 
Table 5. Abstract : $\chi^{2}$, The preferred choice of empirical study about "Family economic conditions adversely affect my ability to achieve a higher degree, also adversely affecting my employment"

\begin{tabular}{|c|c|c|c|c|c|c|c|}
\hline \multirow{2}{*}{$\begin{array}{l}\text { items } \\
\text { independent variables }\end{array}$} & \multicolumn{2}{|c|}{ (1) yes } & \multicolumn{2}{|c|}{ (2) no } & \multicolumn{2}{|c|}{ total } & \multirow{2}{*}{$\begin{array}{l}X^{2} \\
\text { df }\end{array}$} \\
\hline & $\mathrm{N}$ & $\%$ & $\mathrm{~N}$ & $\%$ & $\mathrm{~N}$ & $\%$ & \\
\hline 1gender & & & & & & & 2.029 \\
\hline & & & & & & & 1 \\
\hline (1)male G1 & 34 & 56.7 & 26 & 43.3 & 60 & 25.4 & \\
\hline (2)female G2 & 81 & 46.0 & 95 & 54.0 & 176 & 74.6 & \\
\hline 2department & & & & & & & $10.282 *$ \\
\hline (1)Liberal Arts G1 & 14 & 50.0 & 14 & 50.0 & 28 & 11.9 & \\
\hline (2)Social Science G2 & 30 & 36.6 & 52 & 63.4 & 82 & 34.7 & \\
\hline (3)Living Sciences G3 & 39 & 52.7 & 35 & 47.3 & 74 & 31.4 & \\
\hline (4)Business, Management and Information G4 & 15 & 53.6 & 13 & 46.4 & 28 & 11.9 & \\
\hline (5)Public Administration G5 & 17 & 70.8 & 7 & 29.2 & 24 & 10.2 & \\
\hline $\begin{array}{l}3 \text { highest level of education that the main source of the } \\
\text { economy at your home }\end{array}$ & & & & & & & $\begin{array}{r}.705 \\
1\end{array}$ \\
\hline (1)junior high school, and high schoolG1 & 46 & 52.3 & 42 & 47.7 & 88 & 37.3 & \\
\hline (2) college and graduate G2 & 69 & 46.6 & 79 & 53.4 & 148 & 62.7 & \\
\hline $\begin{array}{l}4 \text { main occupation that the main source of the } \\
\text { economy at your home }\end{array}$ & & & & & & & $\begin{array}{r}1.581 \\
2\end{array}$ \\
\hline (1)military, police and civil service G1 & 29 & 53.7 & 25 & 46.3 & 54 & 22.9 & \\
\hline (2)agriculture, industry and commerce G2 & 72 & 45.9 & 85 & 54.1 & 157 & 66.5 & \\
\hline (3)housekeeper, unemployment, death or retirement G3 & 14 & 56.0 & 11 & 44.0 & 25 & 10.6 & \\
\hline total & 115 & 48.7 & 121 & 51.3 & 236 & 100.0 & \\
\hline 5 your average monthly household income (\$NTD) & & & & & & & 2.548 \\
\hline (1) less than 30 thousand G1 & 23 & 56.1 & 18 & 43.9 & 41 & 17.4 & \\
\hline (2) between 30 and 60 thousand G2 & 51 & 50.5 & 50 & 49.5 & 101 & 42.8 & \\
\hline (3) between 60 and 90 thousand G3 & 24 & 40.7 & 35 & 59.3 & 59 & 25.0 & \\
\hline (4) more than 90 thousand G4 & 17 & 48.6 & 18 & 51.4 & 35 & 14.9 & \\
\hline total & 115 & 48.7 & 121 & 51.3 & 236 & 100.0 & \\
\hline
\end{tabular}

$* \mathrm{p}<.05 \quad * * \mathrm{p}<.01 \quad * * * \mathrm{p}<.001$

For "Important social issues", the aspects of first priority are as follows: "people's livelihood and economy", "education", "environmental protection(including air pollution)","medical","elderly or disadvantaged care", which is shown in Table 6. Again, the aspects of last rank are as follows:"inclusion of immigrant resident", "elderly or disadvantaged care", "drug abuse and crime", "medical", "food safety". In these aspects, students by the gender, department, education, occupation and income all make "people's livelihood and economy" and "education" as the first and second priorities, and make "inclusion of immigrant resident" as the last priority, which is shown in Table 7 and Table 8. Again, for "Definition of success in life", the aspects of first priority are as follows: "healthy", "happy family", "high socioeconomic status and occupation", "self, individualism, freedom", and "make more money, keep pace with the rich"( and "social impact"), which is shown in Table 6. Again, the aspects of last rank are as follows: "self, individualism, freedom", "make more money, keep pace with the rich", "social impact", " high socioeconomic status and occupation", "happy family". In these aspects, students by the gender, department, education, occupation and income all make "healthy" and "happy family" as the first and second prioriies, and make "self, individualism, freedom" or "make more money, keep pace with the rich" as the last priority, which is shown in Table 7 and Table 8.

Table 6. Abstract : frequencies, rank order (priorities)

\begin{tabular}{|c|c|c|c|c|}
\hline \multirow[t]{2}{*}{ questions \& items } & \multicolumn{2}{|c|}{ First priority } & \multicolumn{2}{|c|}{ Last rank } \\
\hline & $\mathrm{N}$ & $\%$ & $\mathrm{~N}$ & $\%$ \\
\hline 1Important social issues & $(1)>(2)>(5$ & (6) & $(7)>(6)>(8$ & (3) \\
\hline (1) people's livelihood and economy & 132 & 55.9 & 19 & 8.1 \\
\hline (2) education & 49 & 20.8 & 16 & 6.8 \\
\hline (3) food safety & 4 & 1.7 & 24 & 10.2 \\
\hline (4) labor rights & 7 & 3.0 & 4 & 1.7 \\
\hline (5) environmental protection (including air pollution) & 12 & 5.1 & 17 & 7.2 \\
\hline (6) elderly or disadvantaged care & 11 & 4.7 & 37 & 15.7 \\
\hline (7) inclusion of immigrant resident & 0 & 0.0 & 62 & 26.3 \\
\hline (8) drug abuse and crime & 9 & 3.8 & 29 & 12.3 \\
\hline (9) medical & 12 & 5.1 & 28 & 11.9 \\
\hline total & 236 & 100.0 & 236 & 100.0 \\
\hline
\end{tabular}

2Definition of success in life

$(6)>(1)>(5)>(2)>(3)(4)$

(2) $>($ (3) $>(4)>(5)>(1)$ 
(1) happy family

(2) self, individualism, freedom

(3) make more money, keep pace with the rich

(4) social impact

(5) high socioeconomic status and occupation

(6) healthy

total

\begin{tabular}{rrrr}
64 & 27.1 & 19 & 8.1 \\
16 & 6.8 & 81 & 34.3 \\
5 & 2.1 & 53 & 22.5 \\
5 & 2.1 & 40 & 16.9 \\
23 & 9.7 & 26 & 11.0 \\
123 & 52.1 & 17 & 7.2 \\
236 & 100.0 & 236 & 100.0 \\
\hline
\end{tabular}

Table 7. Abstract : frequencies, rank order (first priority)

\begin{tabular}{|c|c|c|c|c|c|c|c|}
\hline \multirow[b]{2}{*}{ questions \& items } & \multicolumn{2}{|c|}{ gender } & \multicolumn{5}{|c|}{ department } \\
\hline & male & female & $\begin{array}{l}\text { Liberal } \\
\text { Arts }\end{array}$ & $\begin{array}{c}\text { Social } \\
\text { Science }\end{array}$ & $\begin{array}{l}\text { Living } \\
\text { Sciences }\end{array}$ & $\begin{array}{c}\text { Business, } \\
\text { Management } \\
\text { and } \\
\text { Information }\end{array}$ & $\begin{array}{c}\text { Public } \\
\text { Administration }\end{array}$ \\
\hline 1Important social issues & & & & & & & \\
\hline (1) people's livelihood and economy & 1 & 1 & 1 & 1 & 1 & 1 & 1 \\
\hline (2) education & 2 & 2 & 2 & 2 & 2 & 2 & 2 \\
\hline (3) food safety & 7 & 8 & 3 & 8 & 7 & 6 & 4 \\
\hline (4) labor rights & 3 & 7 & 3 & 6 & 7 & 3 & 7 \\
\hline $\begin{array}{l}\text { (5) environmental protection (including } \\
\text { air pollution) }\end{array}$ & 4 & 3 & 6 & 3 & 5 & 3 & 4 \\
\hline (6) elderly or disadvantaged care & 8 & 3 & 3 & 7 & 4 & 6 & 4 \\
\hline (7) inclusion of immigrant resident & 9 & 9 & 9 & 9 & 7 & 6 & 7 \\
\hline (8) drug abuse and crime & 4 & 6 & 6 & 3 & 6 & 6 & 3 \\
\hline (9) medical & 4 & 3 & 6 & 5 & 3 & 5 & 7 \\
\hline 2Definition of success in life & & & & & & & \\
\hline (1) happy family & 1 & 2 & 2 & 2 & 2 & 2 & 3 \\
\hline (2) self, individualism, freedom & 4 & 4 & 4 & 3 & 4 & 3 & 4 \\
\hline (3) make more money, keep pace with the rich & 5 & 5 & 6 & 5 & 4 & 6 & 4 \\
\hline (4) social impact & 5 & 5 & 4 & 6 & 6 & 5 & 4 \\
\hline (5) high socioeconomic status and occupation & 3 & 3 & 3 & 4 & 3 & 4 & 2 \\
\hline (6) healthy & 2 & 1 & 1 & 1 & 1 & 1 & 1 \\
\hline
\end{tabular}

Table 7. Continue.

\begin{tabular}{lc}
\multicolumn{2}{c}{ education } \\
\hline junior & college \\
high & and \\
school, & graduate \\
and & \\
high & \\
school &
\end{tabular}

\begin{tabular}{ccc} 
& occupation \\
\hline military, & agri- & house- \\
police & culture, & keeper, \\
and & industry & un- \\
civil & and & employ- \\
service & com- & ment, \\
& merce & death or \\
& & retire-
\end{tabular}

\begin{tabular}{cccc}
\multicolumn{4}{c}{ income(NTD) } \\
\hline less & between & between & more \\
than & 30 and & 60 and & than \\
30 & 60 thou- & 90 thou- & 90 \\
thou- & sand & sand & thou- \\
sand & & & sand
\end{tabular}

questions \& items

1Important social issues

(1) people's livelihood and economy

(2) education

(3) food safety

(4) labor rights

(5) environmental protection

ment

(including air pollution)

(6) elderly or disadvantaged care

(7) inclusion of immigrant resident

(8) drug abuse and crime

(9) medical

1
2
7
8
3
5
9
3
5

2Definition of success in life

(1) happy family

(2) self, individualism, freedom

(3) make more money, keep pace with

22

2
4

the rich

(4) social impact

(5) high socioeconomic status and occupation

(6) healthy

4
6
3

1

1
2
8
6
4
4
9
7
3

$\begin{array}{ll}1 & 1 \\ 2 & 2 \\ 8 & 7 \\ 7 & 6 \\ 6 & 3 \\ 4 & 4 \\ 8 & 9 \\ 3 & 8 \\ 4 & 4\end{array}$

$\begin{array}{ll}1 & 1 \\ 2 & 2 \\ 7 & 4 \\ 6 & 6 \\ 3 & 6 \\ 4 & \\ 9 & 6 \\ 8 & 6 \\ 4 & 3\end{array}$

$\begin{array}{lllll}1 & 1 & 1 & 1 & 1 \\ 2 & 2 & 2 & 2 & 2 \\ 4 & 6 & 8 & 5 & 7 \\ 6 & 8 & 6 & 7 & 4 \\ 6 & 4 & 5 & 5 & 3 \\ 6 & 4 & 3 & 7 & 4 \\ 6 & 9 & 9 & 9 & 7 \\ 3 & 3 & 7 & 3 & 7 \\ 4 & 6 & 3 & 3 & 4\end{array}$


Table 8. Abstract : frequencies, rank order (last)

\begin{tabular}{|c|c|c|c|c|c|c|c|}
\hline \multirow[b]{2}{*}{ questions \& items } & \multicolumn{2}{|c|}{ gender } & \multicolumn{5}{|c|}{ department } \\
\hline & male & female & $\begin{array}{l}\text { Liberal } \\
\text { Arts }\end{array}$ & $\begin{array}{c}\text { Social } \\
\text { Science }\end{array}$ & $\begin{array}{c}\text { Living } \\
\text { Sciences }\end{array}$ & $\begin{array}{c}\text { Business, } \\
\text { Management } \\
\text { and } \\
\text { Information }\end{array}$ & $\begin{array}{c}\text { Public } \\
\text { Administration }\end{array}$ \\
\hline 1Important social issues & & & & & & & \\
\hline (1) people's livelihood and economy & 8 & 6 & 6 & 3 & 8 & 6 & 4 \\
\hline (2) education & 6 & 7 & 8 & 5 & 7 & 2 & 7 \\
\hline (3) food safety & 5 & 5 & 2 & 7 & 3 & 6 & 3 \\
\hline (4) labor rights & 8 & 9 & 8 & 9 & 9 & 8 & 8 \\
\hline $\begin{array}{l}\text { (5) environmental protection (including } \\
\text { air pollution) }\end{array}$ & 6 & 8 & 7 & 8 & 6 & 4 & 7 \\
\hline (6) elderly or disadvantaged care & 2 & 2 & 2 & 3 & 2 & 2 & 4 \\
\hline (7) inclusion of immigrant resident & 1 & 1 & 1 & 1 & 1 & 1 & 2 \\
\hline (8) drug abuse and crime & 3 & 4 & 2 & 6 & 4 & 4 & 1 \\
\hline (9) medical & 4 & 3 & 2 & 2 & 4 & 8 & 4 \\
\hline 2Definition of success in life & & & & & & & \\
\hline (1) happy family & 6 & 5 & 6 & 5 & 5 & 6 & 2 \\
\hline (2) self, individualism, freedom & 2 & 1 & 1 & 1 & 1 & 2 & 2 \\
\hline (3) make more money, keep pace with the rich & 1 & 2 & 2 & 2 & 2 & 1 & 4 \\
\hline (4) social impact & 3 & 3 & 3 & 3 & 3 & 2 & 1 \\
\hline (5) high socioeconomic status and occupation & 5 & 4 & 3 & 6 & 4 & 4 & 5 \\
\hline (6) healthy & 4 & 6 & 5 & 4 & 6 & 5 & 6 \\
\hline
\end{tabular}

Table 8. Continue

\begin{tabular}{|c|c|c|c|c|c|c|c|c|c|}
\hline \multirow[b]{2}{*}{ questions \& items } & \multicolumn{2}{|c|}{ education } & \multicolumn{3}{|c|}{ occupation } & \multicolumn{4}{|c|}{ income(NTD) } \\
\hline & $\begin{array}{l}\text { junior } \\
\text { high } \\
\text { school, } \\
\text { and } \\
\text { high } \\
\text { school }\end{array}$ & $\begin{array}{c}\text { college } \\
\text { and } \\
\text { graduate }\end{array}$ & $\begin{array}{l}\text { military, } \\
\text { police } \\
\text { and } \\
\text { civil } \\
\text { service }\end{array}$ & $\begin{array}{c}\text { agri- } \\
\text { culture, } \\
\text { industry } \\
\text { and } \\
\text { com- } \\
\text { merce }\end{array}$ & $\begin{array}{l}\text { house- } \\
\text { keeper, } \\
\text { un- } \\
\text { employ- } \\
\text { ment, } \\
\text { death or } \\
\text { retire- } \\
\text { ment }\end{array}$ & $\begin{array}{c}\text { less } \\
\text { than } 30 \\
\text { thou- } \\
\text { sand }\end{array}$ & $\begin{array}{c}\text { betwee } \\
\text { n } 30 \\
\text { and } \\
60 \\
\text { thou- } \\
\text { sand }\end{array}$ & $\begin{array}{c}\text { between } 60 \\
\text { and } \\
90 \text { thou- } \\
\text { sand }\end{array}$ & $\begin{array}{c}\text { more } \\
\text { than } \\
90 \\
\text { thou- } \\
\text { sand }\end{array}$ \\
\hline 1Important social issues & & & & & & & & & \\
\hline (1) people's livelihood and economy & 7 & 6 & 3 & 6 & 5 & 3 & 8 & 5 & 5 \\
\hline (2) education & 8 & 6 & 3 & 8 & 8 & 6 & 6 & 7 & 5 \\
\hline (3) food safety & 5 & 3 & 6 & 3 & 8 & 6 & 3 & 7 & 5 \\
\hline (4) labor rights & 9 & 9 & 7 & 9 & 6 & 9 & 9 & 9 & 9 \\
\hline $\begin{array}{l}\text { (5) environmental protection } \\
\text { (including air pollution) }\end{array}$ & 6 & 8 & 6 & 6 & 6 & 6 & 7 & 6 & 2 \\
\hline (6) elderly or disadvantaged care & 2 & 2 & 6 & 2 & 2 & 2 & 2 & 3 & 3 \\
\hline (7) inclusion of immigrant resident & 1 & 1 & 1 & 1 & 1 & 1 & 1 & 1 & 1 \\
\hline (8) drug abuse and crime & 3 & 3 & 2 & 3 & 2 & 5 & 4 & 2 & 5 \\
\hline (9) medical & 4 & 3 & 3 & 5 & 4 & 3 & 5 & 3 & 3 \\
\hline $\begin{array}{l}\text { 2Definition of success in life } \\
\text { (1) happy family }\end{array}$ & 5 & 6 & 5 & 5 & 6 & 5 & 4 & 6 & 5 \\
\hline (2) self, individualism, freedom & 1 & 1 & 1 & 1 & 1 & 1 & 1 & 1 & 3 \\
\hline $\begin{array}{l}\text { (3) make more money, keep pace } \\
\text { with the rich }\end{array}$ & 3 & 2 & 1 & 2 & 3 & 2 & 2 & 2 & 1 \\
\hline (4) social impact & 2 & 3 & 3 & 3 & 2 & 3 & 3 & 2 & 1 \\
\hline $\begin{array}{l}\text { (5) high socioeconomic status and } \\
\text { occupation }\end{array}$ & 4 & 4 & 4 & 4 & 3 & 4 & 5 & 4 & 4 \\
\hline (6) healthy & 6 & 5 & 5 & 6 & 3 & 6 & 6 & 5 & 6 \\
\hline
\end{tabular}

\subsubsection{Higher Education and Employability}

In recent decades there have been extensive changes to work and employment, accentuated by the continuing effects of the 2007-2008 downturn. The national policies have particularly considered how to strengthen the alignment of education with the needs of industry. Taiwan is transforming itself into a knowledge economy. The decline in manufacturing jobs and the corresponding shift to health, education and administration is evident. Whilst the increase in personal services and professional or technical employment lends some support to the thesis that knowledge work is increasingly important. These changes are accentuated by austerity policies and uncertainty that people are entering work but many are underemployed. It is working-class students who are most affected by underfunded state provision. Higher education aligns with the needs of the knowledge economy as a key recovery measure from the recession. 


\subsubsection{Struggling to Compete: Class and Difference}

Over the half century, Taiwan has achieved remarkable economic and educational development. From an economic perspective, it has achieved rapid economic growth, with Per Capita GDP ( U.S.\$ ) rising from under US\$154 in the 1951 to more than US\$25,909 in 2019 (Directorate General of Budget, Accounting and Statistics (DGBAS) of Executive Yuan, R. O. C. Taiwan). The Gini coefficient (the measure of inequality in society) was 0.278 by 1980 ; by 2018 it had risen to 0.338, the high level of inequality in Taiwan (DGBAS). The rising share of profits and falling share of wages have had significant consequences for the economy, in particular, leading to a growing concentration of income and wealth among the top 40 per cent of society and the relative impoverishment of the bottom 60 per cent that the average disposable income per household of each fifth (Unit: NT\$, DGBAS) are the follows in 2018: Lowest $20 \%(6.66 \%)$, Second 20\%(12.31\%), Third 20\%(17.15\%), Fourth 20\%(23.38), Highest 20\%(40.51\%). From an educational perspective, it has experienced dramatic expansion, with the participation rate of young people in higher education rising from approximately 20\% in 1950 to almost 99\% in 2019 (Ministry of Education). In this process of dramatic economic and educational transformation, many Taiwanese have benefited from the expansion of educational opportunities. As a result, the majority of Taiwanese believe that they and their children will achieve upward mobility through education if they work hard.

Since the 2000s, income inequality has been growing in Taiwan. This wider troubling economic context is at the core of working-class educational underachievement and provides the backdrop to working-class experiences of schooling. Many working-class students in the study talked about a sense of educational worthlessness and feeling that they were not respected within education. What becomes apparent is how painfully the educational world is experienced by those who occupy an inferior. Working-class relationships to education have been problematic and emotionally charged, inscribing academic failure rather than success. The school system increasingly seems like a mirage. Symbolic violence increasingly dominates working-class young people's thinking and feeling. Some young working-class people feel in relation to circumstances that are beyond their control.

\subsubsection{Social Disadvantage and Social Adversity}

Social problems stemming from inequality have impacted on education system. The integration policy has been successful for incorporating different groups into public school provision. However, students from low socio-economic status (SES) backgrounds, and in remote locations, tend to underestimate their own academic potential, are less willing to take risks. The governments have placed an increasing emphasis on the economic role of education and training and have attempted to reform the education system. Education and other factors have increasingly been presented as the solution to the demands of globalization and economic competition. The government has concentrated on skills and creating a flexible workforce. The failure of the labour market to meet the growing demand for professional employment is particularly acute in Taiwan with large middle classes, mass higher education and wide income inequalities. Education plays a crucial role in this process as young people seek to gain positional advantage by using educational attainment to stand out from the crowd.

\subsubsection{Family Helps to Cope with Labour Market Adversity and Poverty}

Education is a key determinant of success in the labour market, and the effect of parental social status on child educational achievement is an important channel of status transmission. Family help to improve education or labour market outcomes will diminish the likelihood of falling into poverty. For some young people, low education, unemployment and poverty are partly inherited from their parents' generation. Poverty, disadvantage and many of the problems have become a failure of the working classes to equip their children with appropriate personal resources and social skills. Parents affect their children's aspirations and ambitions by education. Higher occupational and social positions come along with a greater stock of resources that can be invested in the children's educational and occupational career. Those factors in parents' backgrounds influenced their children's socialization toward educational upward mobility. It is not possible to develop a social cohesion policy without a structural reduction in inequality and poverty.

\subsection{Educational Systems}

College students in these aspects of gender, education, occupation and income, pose no significant differences in the factor of "educational systems", including the aspects of "Education is considered vital for the formation of a skilled and knowledge-able pool of workers", "The university is understood as saving the working-class subject from me and this is achieved by transforming me into more middle-class versions through the provision of forms of capital" "The mass expansion of higher education holds out the promise of opening up access to working class and other disadvantaged groups, who live at a time when knowledge is seen as the key to competing for economic prosperity", "Getting a good education makes me more socially competitive", "As long as I am in the education system do not become aware of the inequalities and processes of exclusion in the wider society and consequently have an optimistic 
outlook on life", "Creativity and knowledge are as important as natural resources and money capital for the economic success", which is shown in Table 9. In these aspects, the female (mean=23.93) do better than the male $($ mean=23.75) $(\mathrm{t}=-.276, \mathrm{p}>.05)$; students apply for the department "Public Administration" (mean=26.21) do better than those "Social Science" (mean=23.34) $(\mathrm{F}=3.197, \mathrm{p}<.05)$; householders with junior high school and high school $($ mean $=23.93)$ as highest level of education outdo those with college and graduate (mean=23.85) $(\mathrm{t}=.148, \mathrm{p}>.05)$; householders with housekeeper, unemployment, death or retirement (mean=24.36) as occupation outdo those with agriculture, industry and commerce (mean=23.94) and those with military, police and civil service (mean=23.48) $(\mathrm{F}=.476, \mathrm{p}>.05)$; household income between NTD 30 and 60 thousand (mean=24.00) outperform those less than 30 thousand (mean=23.90), those between NTD\$ 60 and 90 thousand (mean=23.61) and those more than 90 thousand $(\mathrm{mean}=23.97)(\mathrm{F}=.128, \mathrm{p}>.05)$.

Table 9. Abstract: Mean, SD, t-test, ANOVA of empirical study about factor "educational systems"

\begin{tabular}{|c|c|c|c|c|c|c|c|c|c|c|c|}
\hline \multirow[t]{2}{*}{$\begin{array}{l}\text { independent } \\
\text { variables }\end{array}$} & \multirow[t]{2}{*}{$\begin{array}{l}\text { number } \\
\mathrm{N}\end{array}$} & \multirow[t]{2}{*}{$\begin{array}{l}\text { Mean } \\
\text { M }\end{array}$} & \multirow[t]{2}{*}{ SD } & \multicolumn{3}{|c|}{$\begin{array}{l}\text { SS(sum of squares of } \\
\text { deviation from mean) }\end{array}$} & \multicolumn{2}{|c|}{ MS(mean square) } & \multirow[t]{2}{*}{$\mathrm{F}$} & \multirow[t]{2}{*}{$\mathrm{t}$} & \multirow{2}{*}{$\begin{array}{l}\text { post-hoc } \\
\text { test } \\
\text { Scheffe }\end{array}$} \\
\hline & & & & $\begin{array}{l}\text { between } \\
\text { groups }\end{array}$ & $\begin{array}{l}\text { within } \\
\text { groups }\end{array}$ & total & $\begin{array}{l}\text { between } \\
\text { groups }\end{array}$ & $\begin{array}{l}\text { within } \\
\text { groups }\end{array}$ & & & \\
\hline 1gender & 236 & & & & & & & & & -.276 & \\
\hline (1)male G1 & 60 & 23.75 & 4.42 & & & & & & & & \\
\hline (2)female G2 & 176 & 23.93 & 3.79 & & & & & & & & \\
\hline 2department & 236 & 23.88 & 3.95 & 192.68 & 3480.00 & 3672.68 & 48.17 & 15.07 & $3.197 *$ & & $\mathrm{G} 5>\mathrm{G} 2$ \\
\hline $\begin{array}{l}\text { (1)Liberal Arts } \\
\text { G1 }\end{array}$ & 28 & 24.61 & 3.27 & & & & & & & & \\
\hline $\begin{array}{l}\text { (2)Social } \\
\text { Science G2 }\end{array}$ & 82 & 23.34 & 4.04 & & & & & & & & \\
\hline $\begin{array}{l}\text { (3)Living } \\
\text { Sciences G3 }\end{array}$ & 74 & 23.80 & 4.38 & & & & & & & & \\
\hline $\begin{array}{l}\text { (4)Business, } \\
\text { Management } \\
\text { and }\end{array}$ & 28 & 22.96 & 3.10 & & & & & & & & \\
\hline $\begin{array}{l}\text { Information G4 } \\
\text { (5)Public } \\
\text { Administration } \\
\text { G5 }\end{array}$ & 24 & 26.21 & 3.02 & & & & & & & & \\
\hline 3education & 236 & & & & & & & & & .148 & \\
\hline $\begin{array}{l}\text { (1)junior high } \\
\text { school, and } \\
\text { high schoolG1 }\end{array}$ & 88 & 23.93 & 4.13 & & & & & & & & \\
\hline $\begin{array}{l}\text { (2) college and } \\
\text { graduate G2 }\end{array}$ & 148 & 23.85 & 3.86 & & & & & & & & \\
\hline 4occupation & 236 & 23.88 & 3.95 & 14.95 & 3657.73 & 3672.68 & 7.48 & 15.70 & .476 & & \\
\hline $\begin{array}{l}\text { (1)military, } \\
\text { police and civil } \\
\text { service G1 }\end{array}$ & 54 & 23.48 & 5.07 & & & & & & & & \\
\hline $\begin{array}{l}\text { (2)agriculture, } \\
\text { industry and } \\
\text { commerce G2 }\end{array}$ & 157 & 23.94 & 3.56 & & & & & & & & \\
\hline $\begin{array}{l}\text { (3)housekeeper, } \\
\text { unemployment, } \\
\text { death or } \\
\text { retirement G3 }\end{array}$ & 25 & 24.36 & 3.66 & & & & & & & & \\
\hline 5income(NTD) & 236 & 23.88 & 3.95 & 6.06 & 3666.62 & 3672.68 & 2.02 & 15.80 & .128 & & \\
\hline $\begin{array}{l}\text { (1) less than } 30 \\
\text { thousand } \mathrm{G} 1\end{array}$ & 41 & 23.90 & 4.54 & & & & & & & & \\
\hline $\begin{array}{l}\text { (2) between } 30 \\
\text { and } 60 \\
\text { thousand G2 }\end{array}$ & 101 & 24.00 & 3.69 & & & & & & & & \\
\hline $\begin{array}{l}\text { (3) between } 60 \\
\text { and } 90 \\
\text { thousand G3 }\end{array}$ & 59 & 23.61 & 4.31 & & & & & & & & \\
\hline $\begin{array}{l}\text { (4) more than } \\
90 \text { thousand } \mathrm{G} 4\end{array}$ & 35 & 23.97 & 3.44 & & & & & & & & \\
\hline$* \mathrm{p}<.05 \quad * *$ & $<.01$ & $* * * p$ & 001 & & & & & & & & \\
\hline
\end{tabular}


For "Having a college degree does not bring too much money or obvious life change", students choose "yes"(51.7\%) more than "no" $(48.3 \%)$, which is shown in Table 10. In these aspects, $58.3 \%$ of the male prefer to choose "yes" and $50.6 \%$ of the female prefer to choose "no" $(\chi 2=1.420, \mathrm{p}>.05) ; 60.7 \%$ of students apply for the department "Liberal Arts" prefer to choose "no", $53.7 \%$ of students apply for the department "Social Science" prefer to choose "no", $58.1 \%$ of students apply for the department "Living Sciences" prefer to choose "yes", $60.7 \%$ of students apply for the department "Business, Management and Information" prefer to choose "yes", $54.2 \%$ of students apply for the department "Public Administration" prefer to choose "yes" $(\chi 2=4.857, \mathrm{p}>.05) ; 51.1 \%$ of householders with junior high school and high school as highest level of education prefer to choose "yes" and 52.0\% those with college and graduate also prefer to choose "yes" $(\chi 2=.018$, $\mathrm{p}>.05) ; 64.8 \%$ of householders with military, police and civil service as occupation prefer to choose "yes", $52.9 \%$ of those with agriculture, industry and commerce prefer to choose "no", and $52.0 \%$ of those with housekeeper, unemployment, death or retirement prefer to choose "yes" $(\chi 2=5.031, p>.05) ; 51.2$ of household income with less than 30 thousand prefer to choose "yes", $52.5 \%$ of those between NTD\$ 30 and 90 thousand prefer to choose "yes", and 51.4 of those with more than 90 thousand prefer to choose "no" $(\chi 2=.182, \mathrm{p}>.05)$. For "Important social issues", the aspect of education is prioritized as the second, which is shown in Table 6、7、8.

Table 10. Abstract : $\chi^{2}$, The preferred choice of empirical study about "Having a college degree does not bring too much money or obvious life change"

\begin{tabular}{|c|c|c|c|c|c|c|c|}
\hline \multirow{2}{*}{$\begin{array}{l}\text { items } \\
\text { independent variables }\end{array}$} & \multicolumn{2}{|c|}{ (1) yes } & \multicolumn{2}{|c|}{ (2) no } & \multicolumn{2}{|c|}{ total } & \multirow{2}{*}{$\frac{x^{2}}{d f}$} \\
\hline & $\mathrm{N}$ & $\%$ & $\mathrm{~N}$ & $\%$ & $\mathrm{~N}$ & $\%$ & \\
\hline 1gender & & & & & & & 1.420 \\
\hline (1)male G1 & 35 & 58.3 & 25 & 41.7 & 60 & 25.4 & 1 \\
\hline (2)female G2 & 87 & 49.4 & 89 & 50.6 & 176 & 74.6 & \\
\hline 2department & & & & & & & 4.857 \\
\hline (1)Liberal Arts G1 & 11 & 39.3 & 17 & 60.7 & 28 & 11.9 & 4 \\
\hline (2)Social Science G2 & 38 & 46.3 & 44 & 53.7 & 82 & 34.7 & \\
\hline (3)Living Sciences G3 & 43 & 58.1 & 31 & 41.9 & 74 & 31.4 & \\
\hline (4)Business, Management and Information G4 & 17 & 60.7 & 11 & 39.3 & 28 & 11.9 & \\
\hline (5)Public Administration G5 & 13 & 54.2 & 11 & 45.8 & 24 & 10.2 & \\
\hline $\begin{array}{l}3 \text { highest level of education that the main source } \\
\text { of the economy at your home }\end{array}$ & & & & & & & $\begin{array}{r}.018 \\
1\end{array}$ \\
\hline (1)junior high school, and high schoolG1 & 45 & 51.1 & 43 & 48.9 & 88 & 37.3 & \\
\hline (2) college and graduate G2 & 77 & 52.0 & 71 & 48.0 & 148 & 62.7 & \\
\hline $\begin{array}{l}4 \text { main occupation that the main source of the } \\
\text { economy at your home }\end{array}$ & & & & & & & $\begin{array}{r}5.031 \\
2\end{array}$ \\
\hline (1)military, police and civil service G1 & 35 & 64.8 & 19 & 35.2 & 54 & 22.9 & \\
\hline (2)agriculture, industry and commerce G2 & 74 & 47.1 & 83 & 52.9 & 157 & 66.5 & \\
\hline $\begin{array}{l}\text { (3)housekeeper, unemployment, death or } \\
\text { retirement G3 }\end{array}$ & 13 & 52.0 & 12 & 48.0 & 25 & 10.6 & \\
\hline $\begin{array}{l}5 \text { your average monthly household income } \\
\text { ( } \$ \text { NTD) }\end{array}$ & & & & & & & $\begin{array}{r}.182 \\
3\end{array}$ \\
\hline (1) less than 30 thousand G1 & 21 & 51.2 & 20 & 48.8 & 41 & 17.4 & \\
\hline (2) between 30 and 60 thousand G2 & 53 & 52.5 & 48 & 47.5 & 101 & 42.8 & \\
\hline (3) between 60 and 90 thousand G3 & 31 & 52.5 & 28 & 47.5 & 59 & 25.0 & \\
\hline (4) more than 90 thousand G4 & 17 & 48.6 & 18 & 51.4 & 35 & 14.8 & \\
\hline total & 122 & 51.7 & 114 & 48.3 & 236 & 100.0 & \\
\hline
\end{tabular}

$* \mathrm{p}<.05 \quad * * \mathrm{p}<.01 \quad * * * \mathrm{p}<.001$

\subsubsection{Equity in Higher Education}

Human capital was considered an intangible asset with the capacity to enhance productivity and employability so that the government embarked on expansions of the higher education systems. Taiwan made employability one of its priorities for national policy action on youth employment, along with entrepreneurship and employment creation. The widening participation policy promotes the opportunity of successful participation in higher education to all, and emphasizes the imperative to develop human capital to create competitive knowledge economies. Parents believe that their children need a university education to get on in life. Especially, those working-class parents see a degree as desirable and hope that their children will continue to higher education. A university degree has been a sound investment, and the knowledge-based economy demands a particular investment in the young who risked high unemployment and low pay. There is a clear graduate premium in earnings, which applies especially for female. One of 
the best predictors of your earnings is your level of education. The objective for equity in higher education is to ensure that people from all have the opportunity to participate successfully in higher education.

\subsubsection{Increasing Demand for Education in a Globalized Environment}

An important influence of globalization is to include demands for expanding higher education. The educational change should be seen as a precursor for more fundamental social, economic and cultural transformations predicated on alternative values. The government has obsessed at the idea of increasing the supply of qualifications to have a highly skilled workforce to remain competitive in the global knowledge economy. The gains from university are not just in terms of acquisition of symbolic capital, in the form of elite types of knowledge which will lead to the securing of high levels of economic capital. Education gives individuals increased prestige, increased earning and better opportunities to wield some political power, and seems to be a stronger factor moving people away from a traditional working class worldview. There has been a considerable expansion of higher education over the last 50 years in Taiwan. The number of higher education institutions has grown from 85 in 1968 to 163 in 2010, and to 152 in 2019 after a number of mergers. The number of higher education students has grown from 161,337 in 1968 to 1,343,603 in 2010, and to 1,213,172 in 2019(Ministry of Education). Taiwan has higher proportions of participation and graduation in higher education.

Changes in technology and academic work have reshaped the nature of higher education. Policy and funding reforms, introduction of the loans scheme, have reshaped patterns of participation. The government has sought to tie employability to issues of access to higher education and economic competitiveness. The concept of employability is driving higher education policy as governments see their economies linked to a trained workforce. If education does not enable youth to have skills to obtain employment, we have a problem. Since 2008 job opportunities for young people have been hard hit by recession, structural changes in the Taiwan economy have driven a decline in youth employment. Taiwan has witnessed increasing job polarization, a decline in the share of workers in the middle of the workforce, and increases in the proportions of workers in high- and low-skill jobs. The decline in middle-skill employment went hand in hand with a decrease of standard work contracts; and workers taking on low- and high-skill jobs were increasingly likely to be self-employed, part-timers or temporary workers- non-standard employment or atypical contracts.

\subsubsection{From Equity to Excellence}

In 2000s, Ministry of Education (MOE) enacted a collection of initiatives that aimed to better equip students to face the realities of shifting social, economic, and political conditions. Government reports emphasized that the problems experienced by the youths necessitated reforms. Particular attention is devoted to the issue of equity, and how the relaxed education programs are affecting the learning opportunities and performance of different groups of students. Upwardly mobile pathways tend to decrease for children with lower than tertiary educated parents and increase for students with tertiary educated parents. Social class origin was important for educational attainment in our students of this study. These findings point to the importance of societal-level policies that reduce social inequality in education as a prerequisite for social mobility. The objective for equity in higher education is to ensure that people from all groups have the opportunity to participate successfully in higher education. The emergence of the social change are linked to educational reforms, such as the extension of compulsory school years and the expansion of upper secondary schools and higher education, with distance-education concentrations that especially attracted the working class.

\subsection{Individual Motives}

College students in these aspects of gender, education, occupation and income, pose no significant differences in the factor of "individual motives", including the aspects of "I let go of the past, have a future, and believe tomorrow will be better", "I agree "living well is the best revenge"", "I agree "active, rebellious and competitive social ethos"”, "I agree "making life more interesting, more diverse, and more inspiring"", "I agree to create a way of life that lets people enjoy wealthy success, at the same time gets a rebellious free soul", "I can stand out with my own strength", which is shown in Table 11. In these aspects, the female $(m e a n=23.94)$ do better than the male (mean=23.23) $(\mathrm{t}=-1.161, \mathrm{p}>.05)$; students apply for the department "Public Administration" (mean=26.25) do better than those "Social Science" $(m e a n=23.44)$ and those "Living Science" (mean=23.26) $(\mathrm{F}=3.264, \mathrm{p}<.05)$; householders with junior high school and high school (mean=24.36) as highest level of education outdo those with college and graduate (mean=23.40) $(\mathrm{t}=1.828$, $\mathrm{p}>.05$ ); householders with housekeeper, unemployment, death or retirement (mean=24.12) as occupation outdo those with agriculture, industry and commerce $(m e a n=23.73)$ and those with military, police and civil service (mean=23.67) $(\mathrm{F}=.127, \mathrm{p}>.05)$; household income between NTD\$ 60 and 90 thousand (mean=24.15) outperform those less than 30 thousand (mean=23.63), those between NTD $\$ 30$ and 60 thousand (mean=23.70) and those more than 90 thousand $($ mean $=23.40)(\mathrm{F}=.322, \mathrm{p}>.05)$. 
Table 11. Abstract: Mean, SD, t-test, ANOVA of empirical study about factor "individual motives"

\begin{tabular}{|c|c|c|c|c|c|c|c|c|c|c|c|}
\hline \multirow[t]{2}{*}{$\begin{array}{l}\text { independent } \\
\text { variables }\end{array}$} & \multirow[t]{2}{*}{$\begin{array}{l}\text { number } \\
\mathrm{N}\end{array}$} & \multirow[t]{2}{*}{$\begin{array}{l}\text { Mean } \\
\text { M }\end{array}$} & \multirow[t]{2}{*}{ SD } & \multicolumn{3}{|c|}{$\begin{array}{l}\text { SS(sum of squares } \\
\text { deviation from mean) }\end{array}$} & \multicolumn{2}{|c|}{ MS(mean square) } & \multirow[t]{2}{*}{$\mathrm{F}$} & \multirow[t]{2}{*}{$\mathrm{t}$} & \multirow{2}{*}{$\begin{array}{l}\text { post-hoc } \\
\text { test } \\
\text { Scheffe }\end{array}$} \\
\hline & & & & $\begin{array}{l}\begin{array}{l}\text { between } \\
\text { groups }\end{array} \\
\end{array}$ & $\begin{array}{l}\text { within } \\
\text { groups }\end{array}$ & total & $\begin{array}{l}\text { between } \\
\text { groups }\end{array}$ & $\begin{array}{l}\text { within } \\
\text { groups }\end{array}$ & & & \\
\hline 1gender & 236 & & & & & & & & & -1.161 & \\
\hline (1)male G1 & 60 & 23.23 & 4.15 & & & & & & & & \\
\hline (2)female G2 & 176 & 23.94 & 3.76 & & & & & & & & \\
\hline 2department & 236 & 23.76 & 3.87 & 188.27 & 3330.96 & 3519.23 & 47.07 & 14.42 & $3.264 *$ & & $\begin{array}{l}\mathrm{G} 5>\mathrm{G} 2 \\
\mathrm{G} 5>\mathrm{G} 3\end{array}$ \\
\hline $\begin{array}{l}\text { (1)Liberal Arts } \\
\text { G1 }\end{array}$ & 28 & 24.29 & 3.81 & & & & & & & & \\
\hline $\begin{array}{l}\text { (2)Social } \\
\text { Science G2 }\end{array}$ & 82 & 23.44 & 3.58 & & & & & & & & \\
\hline $\begin{array}{l}\text { (3)Living } \\
\text { Sciences G3 }\end{array}$ & 74 & 23.26 & 4.29 & & & & & & & & \\
\hline $\begin{array}{l}\text { (4)Business, } \\
\text { Management } \\
\text { and }\end{array}$ & 28 & 23.36 & 3.60 & & & & & & & & \\
\hline $\begin{array}{l}\text { Information G4 } \\
\text { (5)Public } \\
\text { Administration } \\
\text { G5 }\end{array}$ & 24 & 26.25 & 3.00 & & & & & & & & \\
\hline 3education & 236 & & & & & & & & & 1.828 & \\
\hline $\begin{array}{l}\text { (1)junior high } \\
\text { school, and } \\
\text { high schoolG1 }\end{array}$ & 88 & 24.36 & 4.02 & & & & & & & & \\
\hline $\begin{array}{l}\text { (2) college and } \\
\text { graduate G2 }\end{array}$ & 148 & 23.40 & 3.74 & & & & & & & & \\
\hline 4occupation & 236 & 23.76 & 3.87 & 3.83 & 3515.40 & 3519.23 & 1.91 & 15.09 & .127 & & \\
\hline $\begin{array}{l}\text { (1)military, } \\
\text { police and civil } \\
\text { service G1 }\end{array}$ & 54 & 23.67 & 4.87 & & & & & & & & \\
\hline $\begin{array}{l}\text { (2)agriculture, } \\
\text { industry and } \\
\text { commerce G2 }\end{array}$ & 157 & 23.73 & 3.64 & & & & & & & & \\
\hline $\begin{array}{l}\text { (3)housekeeper, } \\
\text { unemployment, } \\
\text { death or } \\
\text { retirement G3 }\end{array}$ & 25 & 24.12 & 2.79 & & & & & & & & \\
\hline 5income(NTD) & 236 & 23.76 & 3.87 & 14.61 & 3504.63 & 3519.23 & 4.87 & 15.11 & .322 & & \\
\hline $\begin{array}{l}\text { (1) less than } 30 \\
\text { thousand G1 }\end{array}$ & 41 & 23.63 & 4.54 & & & & & & & & \\
\hline $\begin{array}{l}\text { (2) between } 30 \\
\text { and } 60 \\
\text { thousand G2 }\end{array}$ & 101 & 23.70 & 3.90 & & & & & & & & \\
\hline $\begin{array}{l}\text { (3) between } 60 \\
\text { and } 90 \\
\text { thousand G3 }\end{array}$ & 59 & 24.15 & 3.75 & & & & & & & & \\
\hline $\begin{array}{l}\text { (4) more than } \\
90 \text { thousand G4 }\end{array}$ & 35 & 23.40 & 3.15 & & & & & & & & \\
\hline
\end{tabular}

For "My income is not comparable to others, less able to maintain a life comparable to others, and more alienated from society", college students choose "no" $(66.1 \%)$ more than "yes" $(33.9 \%)$, which is shown in Table 12 . In these aspects, $51.7 \%$ of the male prefer to choose "yes" and $72.2 \%$ of the female prefer to choose "no" $(\chi 2=11.336, p<.01) ; 64.3 \%$ of students apply for the department "Liberal Arts" prefer to choose "no", 72.0\% of students apply for the department "Social Science" prefer to choose "no", 67.6\% of students apply for the department "Living Sciences" prefer to choose "no", 57.1\% of students apply for the department "Business, Management and Information" prefer to choose "no", 54.2\% of students apply for the department "Public Administration" prefer to choose "no" ( $\chi 2=3.893, p>.05) ; 59.1 \%$ of householders with junior high school and high school as highest level of education prefer to choose "no" and 70.3\% those with college and graduate also prefer to choose "no" $(\chi 2=3.078, p>.05) ; 64.8 \%$ of householders with military, police and civil service as occupation prefer to choose "no", $68.8 \%$ of those with agriculture, industry and commerce 
prefer to choose "no", and $52.0 \%$ of those with housekeeper, unemployment, death or retirement prefer to choose "no" $(\chi 2=2.765, p>.05) ; 58.5$ of household income with less than 30 thousand prefer to choose "yes", $72.3 \%$ of those between NTD\$ 30 and 60 thousand prefer to choose "no", 74.6\% of those between NTD\$ 60 and 90 thousand prefer to choose "no", and $62.9 \%$ of those with more than 90 thousand prefer to choose "no" $(\chi 2=14.882, \mathrm{p}<.01)$. We can find a significant effect of upward social mobility on chances of attaining a higher education degree, and a higher occupational and social position. Education is important as a means to success in a meritocratic society.

Table 12. Abstract: $\chi^{2}$, The preferred choice of empirical study about "My income is not comparable to others, less able to maintain a life comparable to others, and more alienated from society"

\begin{tabular}{|c|c|c|c|c|c|c|c|}
\hline \multirow{2}{*}{$\begin{array}{l}\text { items } \\
\text { independent variables }\end{array}$} & \multicolumn{2}{|c|}{ (1) yes } & \multicolumn{2}{|c|}{ (2) no } & \multicolumn{2}{|c|}{ total } & \multirow{2}{*}{$\frac{x^{2}}{d f}$} \\
\hline & $\mathrm{N}$ & $\%$ & $\mathrm{~N}$ & $\%$ & $\mathrm{~N}$ & $\%$ & \\
\hline 1gender & & & & & & & $11.336 * *$ \\
\hline (1)male G1 & 31 & 51.7 & 29 & 48.3 & 60 & 25.4 & 1 \\
\hline (2)female G2 & 49 & 27.8 & 127 & 72.2 & 176 & 74.6 & \\
\hline 2department & & & & & & & 3.893 \\
\hline (1)Liberal Arts G1 & 10 & 35.7 & 18 & 64.3 & 28 & 11.9 & \\
\hline (2)Social Science G2 & 23 & 28.0 & 59 & 72.0 & 82 & 34.7 & \\
\hline (3)Living Sciences G3 & 24 & 32.4 & 50 & 67.6 & 74 & 31.4 & \\
\hline (4)Business, Management and Information G4 & 12 & 42.9 & 16 & 57.1 & 28 & 11.9 & \\
\hline (5)Public Administration G5 & 11 & 45.8 & 13 & 54.2 & 24 & 10.2 & \\
\hline $\begin{array}{l}3 \text { highest level of education that the main source } \\
\text { of the economy at your home }\end{array}$ & & & & & & & $\begin{array}{r}3.078 \\
1\end{array}$ \\
\hline (1)junior high school, and high schoolG1 & 36 & 40.9 & 52 & 59.1 & 88 & 37.3 & \\
\hline (2) college and graduate G2 & 44 & 29.7 & 104 & 70.3 & 148 & 62.7 & \\
\hline $\begin{array}{l}4 \text { main occupation that the main source of the } \\
\text { economy at your home }\end{array}$ & & & & & & & $\begin{array}{r}2.765 \\
2\end{array}$ \\
\hline (1)military, police and civil service G1 & 19 & 35.2 & 35 & 64.8 & 54 & 22.9 & \\
\hline (2)agriculture, industry and commerce G2 & 49 & 31.2 & 108 & 68.8 & 157 & 66.5 & \\
\hline $\begin{array}{l}\text { (3)housekeeper, unemployment, death or } \\
\text { retirement G3 }\end{array}$ & 12 & 48.0 & 13 & 52.0 & 25 & 10.6 & \\
\hline $\begin{array}{l}5 \text { your average monthly household income } \\
\text { (\$NTD) }\end{array}$ & & & & & & & $\begin{array}{r}14.882 * * \\
3\end{array}$ \\
\hline (1) less than 30 thousand G1 & 24 & 58.5 & 17 & 41.5 & 41 & 17.4 & \\
\hline (2) between 30 and 60 thousand G2 & 28 & 27.7 & 73 & 72.3 & 101 & 42.8 & \\
\hline (3) between 60 and 90 thousand G3 & 15 & 25.4 & 44 & 74.6 & 59 & 25.0 & \\
\hline (4) more than 90 thousand G4 & 13 & 37.1 & 22 & 62.9 & 35 & 14.8 & \\
\hline total & 80 & 33.9 & 156 & 66.1 & 236 & 100.0 & \\
\hline
\end{tabular}

$* \mathrm{p}<.05 \quad * * \mathrm{p}<.01 \quad * * * \mathrm{p}<.001$

\subsubsection{New Expectations and Aspirations}

Today's labour markets and working life can be described as insecure, unstable and risky. The journey into adulthood is more complex that few gain full-time work immediately after leaving school, and secure employment has become difficult to obtain. Social structures appear less predictable and traditional patterns of social reproduction have been disturbed. The expansion of higher education and the uncertainties of the job market increase the competition for the elusive career. The dominant class possess the necessary capitals, cultural and social as well as economic, to secure their children places. The gains from university are not just in terms of acquisition of symbolic capital, in the form of qualifications which will secure high levels of economic capital. Capital acquired through education and work experience may be vital in enabling individuals to adapt to the changing economic environment with optimism. Social networks formed at universities are also crucial to the reproduction of dominant class positions. Issues around educational opportunity, and social and economic inequalities had come to the fore.

\subsubsection{Social Origins}

Those who take up higher education differ in their educational biography depending on their social origin. Due to the socially selective education system, tertiary students from lower social origins might be a positive selection in terms of the qualities that might compensate for disadvantages and cancel out the effect of social origin. Increasing the non-standard pathways to higher education, which are used more often by students from a lower social background, seems to be one possible way to reduce social inequality in access to higher education. College students of National 
Open University, Taiwan, have gained a high level of autonomy, so that their decision whether or not to complete tertiary studies no longer depends on their parents. Students who entered higher education are less influenced by their parents because they are older than students who have only completed school. These students from a lower social background may be a selection of more ambitious students than their counterparts with a higher social background. The resulting pathways should be upwardly mobile.

\subsubsection{Gender Inequality}

Because educational attainment increased more strongly for female than for male, it is interesting to ask whether social inequalities in educational attainment have developed differently according to gender. Education has become an increasingly important determinant of female class position that male in these classes are more likely to inherit the family business, making them less dependent on education. Female are more likely to live in poverty than are men, and are paid less. Since the gap in wages contributes to the gender gap in wealth and status, the wage gap may be an underlying problem. Mobility among the female is higher compared to the male, indicating wider acceptability of the female in diversified occupational positions. Female envisaged that completion of a university degree was the most tangible route towards a professional career, so that they were immersed in the university study. They wanted financial security and a good job which would provide her with some social status and recognition. This desire to improve the circumstances of existing family and ensure improved living conditions for their future family was a common narrative amongst the female.

\section{Discussion}

The author used data from the LSS survey to examine the chances of attaining a higher education degree in college students, and found a significant effect of upward mobility: together with cultural, economic, and social capital. These determinants seem to explain the impact of upward mobility on chances of attaining a higher education degree. The educational qualification translates into social status that is related to resources. The study reflects the combined effects of recent changes to employment structure, education reform and cultural narratives about social mobility and educational inequality.

\subsection{Education Systems as Products of Inequality}

Educational achievement is one of factors operating to produce social inequality (Robin Simmons, Ron Thompson and Lisa Russell, 2014). Such structures as the academic-vocational divide of institutions, play a key role in reproducing inequalities, diverting working-class people onto lower-status vocational tracks. The empirical results mean that "The priority of predictors on "I believe that society is meritocratic, and that I can shape my own fate and that political engagement therefore makes sense" is as follows: the factor "societal structures", "individual motives" and "educational systems"', "Educational upward mobility is a phenomenon of social change that is embedded in changing social structures, but the factor "educational systems" is least valued", "Schools enable and impede social upward mobility", "the majority of Taiwanese believe that they and their children will achieve upward mobility through education if they work hard", and that "Symbolic violence increasingly dominates working-class young people's thinking and feeling". Some young working-class feel in relation to circumstances that are beyond their control. The project of creating in Taiwan a more open society, through economic expansion, educational reform and egalitarian social policies, has signally succeeded to secure its objectives. In Taiwan, class inequality has been described as essentially unchanging. Whilst young people with high levels of educational attainment, particularly those from middle-class backgrounds, were able to take advantage of increasing opportunities in higher education. Although $66.5 \%$ of students who took part in our study had parents in work, these parents were largely engaged in ordinary working-class employment, including manual work or routine white-collar employment in factories and offices. The parents of other participants, who were currently not in work, had usually held similar jobs in the past. Most participants - whether from families in work or not - had experienced the reproduction in their own emerging adulthood.

\subsection{Structural Determinants Affect Individual Educational Chances Above Talent and Effort}

The experience of the parents shapes the opportunities of their offspring through the transmission of resources and cultural capital (Márton Medgyesi, 2018). A well educated parent or a parent in a higher status job may have the cultural resources, social connections or whatever to land their child a higher paying job (Gary N. Marks, 2013). Family plays a role in mitigating the adversity and poverty. The privilege of the middle classes are attributable to competent personal strength, while the struggling working class can be defined as victims of parental incompetence (Val Gillies, 2013). A family's financial resources play an important role in student achievement through the investment in education. The widening income gap may lead to a growing gap in education opportunities (Soo-yong Byun and Kyung-keun Kim, 2010; David Post, 2010; Gary N. Marks, 2013; Márton Medgyesi, 2018). Increasing school choice and grouping would lead to the greater socioeconomic polarization of students because disadvantaged students would more likely be placed in less desirable classes (Soo-yong Byun and Kyung-keun Kim, 2010). There are structural determinants such as the 
level of differentiation of an education system that affects individual educational chances above talent and effort Sophie Hahn, 2016).

\subsection{Working-Class Relationships to Education Have Been Problematic}

Education represents an accumulation of cultural capital (John McAdams, 2015). The link between social origin and educational attainment plays an essential role because social status depends on educational qualifications (Sophie Hahn, 2016). What becomes apparent is how painfully the educational world is experienced by those who occupy an inferior position. Working-class relationships to education have always been inscribing academic failure (Diane Reay, 2013). But schools force the working-class to recognize the superiority of the standards of the dominant class, thus legitimating their failure to succeed as a personal failure, not a social injustice that Bourdieu calls it symbolic violence (Gartman David, 2013). Many working-class students in the study talked about a sense of educational worthlessness that "Having a college degree does not bring too much money or obvious life change". Education has been recognized as playing a role in reproducing class conditions rather than promoting social mobility. There have been growing concerns with regard to whether the gap in student achievement among students with differing socioeconomic backgrounds will continue to widen. Institutional educational changes can make a difference in educational inequality (Soo-yong Byun and Kyung-keun Kim, 2010).

\subsection{Bachelor Degree is Tangible Route Towards a Professional Career}

The empirical results mean that "For important social issues, the aspect of education is prioritized as the second". The government has obsessed at the idea of increasing the supply of qualifications to have a highly skilled workforce to remain competitivey. Those young are encouraged to raise their educational aspirations and the government is selling a dream but the young end up living a nightmare. Students envisaged that completion of a bachelor degree was the most tangible route towards a professional career (Steven Roberts and Sarah Evans, 2013). The mass expansion of higher education is defined as one of the important social transformations that it holds out the promise of opening up access to those working-class and disadvantaged groups (Ann-Marie Bathmaker, Nicola Ingram, Jessie Abrahams, Anthony Hoare, Richard Waller and Harriet Bradley, 2016). Family background might have an effect on children's outcomes at school (Márton Medgyesi, 2018). Educational expansion might affect social fluidity so that parents want their children to attend college, and stress to their children that education is the only way to obtain stable employment (Sophie Hahn, 2016; Antonia Kupfer, 2015).

\subsection{Educational Reform is the Key to Overcoming Social and Economic Inequalities}

Educational upward mobility requires more than individual talent and effort, and sometimes different ingredients such as the education system. Higher Education systems are subject to multiple expectations and demands such as equity, excellence and cultural heritage (Penny Jane Burke and Yu-Ching Kuo, 2015). Taiwan has enacted a series of reforms as a means of responding to challenges. For example, the government has embarked on reform efforts aimed at reducing the number of higher education institutions through voluntary mergers, with the aims of enhancing quality and global excellence. Equity in education means that students' socioeconomic status has little impact on how well they learn in school (Pasi Sahlberg, 2016). Taiwan transforms itself into knowledge economies focused on technological and creative industries that people engage in continuous pedagogic reformations and cope with the new requirements of work and life. The increased investment in education and training will lead to social and economic advancement. An improved education system is the key to overcoming social and economic inequalities (Robin Simmons, Ron Thompson and Lisa Russell, 2014).

\subsection{Higher Education Promotes Social Inclusion}

The role of universities as drivers of economic growth was paired with a belief in the need for higher education to promote fairness and social inclusion. "Fair Chance for All" created a unified national system of higher education, and led to a transformative expansion of student enrolments. The reforms linked increased participation to economic imperatives, but also recognised higher education's social role (Andrew Harvey, Catherine Burnheim , and Matthew Brett, 2016). If education produces human capital, which determines marginal productivity, then education-determined inequality of skills and productivity is responsible for the growing income inequality (Simon Marginson, 2016A). Education opportunity in schooling is stratified according to social class. Those young people and their families make very different choices about work and education destinations based on their social class (Emmaline Bexley, 2016).

\subsection{Education Is the Distinctive Form of Human Capital}

The growth of the knowledge economy, open innovation, and entrepreneurship, represent the global changes that make demands on lifestyle structures (Daniele Morselli, 2015). Youth employment is characterised by high shares of temporary and part-time work (Márton Medgyesi, 2018). A number of contextual factors underlie the movement from formal employment to freelance working arrangements (Frederick Harry Pitts, 2018). The entrepreneur realises the 
human potential for creativity and drives social progress through individual aspiration (Stephanie Taylor, 2018). Lifestyle entrepreneurship is an economic activity that is conducted for altering the personal lifestyle (Hanna-Mari Ikonen, 2018). Education is both a form of cultural consumption and the distinctive form of human capital for the new class. The relationship between education and entrepreneurship worldview is a somewhat complex one. One indication of workers' increasing acceptance of change is through their take-up of education and training in new skills (Stephanie Taylor and Susan Luckman, 2018). Talking about technical and vocational education and training (TVET), skilled technicians are the backbone of competiveness and wealth (Daniele Morselli, 2015; Lin Mei-Ling, 2019). In Taiwan, small and medium-sized enterprises (SMEs) play a major role in promoting innovation and employment. SMEs need innovation to thrive in the market, and this can come from entrepreneurs but also from the employees who are the TVET graduates. Vocational education is located in a prominent position to support innovation in SMEs (Daniele Morselli, 2015).

\subsection{Investments in Female Education are Particularly Effective in Reducing Poverty}

Social reproduction continues to operate, but their trajectories remain influenced by the class and gender. The social class inequalities in education and high levels of income inequality, provide obstacles to individual mobility (Robin Simmons, Ron Thompson and Lisa Russell, 2014). Despite an increase in the educational level, social origins strongly determine educational chances. Students from higher social backgrounds will succeed because they can rely on their parents' resources (Sophie Hahn, 2016). The empirical results mean that "My income is not comparable to others, less able to maintain a life comparable to others, and more alienated from society", female students choose "no" $(72.2 \%)$ more than the male choose "no"(48.3\%). Gendered patterns of educational performance have intensified social congestion as young women compete for a livelihood with young men (Robin Simmons, Ron Thompson and Lisa Russell, 2014). However, female downward mobility is declining, whereas upward mobility is increasing. The reason is that educational attainment has increased more strongly for women than for men (Sophie Hahn, 2016). Poverty strikes female and male equally, but investments in the female education are particularly effective in reducing poverty (Katja $\mathrm{M}$. Guenther, Matthew C. Mahutga , and Panu Suppatkul, 2016).

\subsection{Education Plays the Major Role in the Link between Origin and Destination Class}

Threating our educational system is not that too few working-class students get to college, but that education favors inequality rather than equality (Antonia Kupfer, 2015). Social mobility is not based on effort alone but influenced by position and resources. The educational institutions play a crucial role in enabling only certain upward mobility and impeding it (Antonia Kupfer, 2015). One result of the study shows that no single social factor dictates educational upward mobility. We will explain the life as necessary to understand its impact on this individual's social upward mobility (Antonia Kupfer, 2015). Studies on social mobility and on educational inequality are divided over the question whether there has been a trend towards more equal chances to obtain educational levels and social class positions. There continue to be large differences in educational and occupational chances based on social origin that education plays the major role in the link between origin and destination class (Sophie Hahn, 2016).

\section{Conclusions}

\subsection{Challenges and Issues}

\subsubsection{Inequality is viewed as an Individual Responsibility, not the Structural Relations}

Social inequalities in educational decisions emerge because persons from higher classes expect higher benefits from educational options that lead to higher social positions (Sophie Hahn, 2016). The socio-economic adversity can be overcome by enabling access to a wide range of educational opportunities (Lyn Tett, 2018). Education is considered as a connection between social status of origin and social position of destination (Sophie Hahn, 2016). Access to higher education may contribute to increase opportunities for upward social mobility. Class differences are relevant for understanding the mechanisms of social inequality (Liza Reisel, 2013). Decline in social mobility implies increase in social and economic inequality. While access to education plays a role in upward social mobility, the assistance provided by parents to their children seems to exert an even more significant influence (Emmanuel Jean Francois, 2015). Inequality is viewed as an individual responsibility, not the consequence of structural relations in society or a public responsibility. Thus, education should have become more affordable for the lower classes, and class differences should decline (Sophie Hahn, 2016).

\subsubsection{Intensifying Investments in Human Capital is the Future Priority}

Social inequalities are pronounced in Taiwan. This situation is due to several factors among which we highlight the increase in unemployment rates, precariousness and poverty as significant drivers of inequalities. Analysis of the empirical data led to a new realization of the importance of educational upward mobility. Several subjects from precarious social backgrounds sought security in higher education. The educational institutions should be 
nonhierarchical for educational reforms aiming for greater social equality (Antonia Kupfer, 2015). This study can be read as a special account in the process of social change by demonstrating how structural changes lead to the development of new conditions that enabled the students to seek higher education, to change class, and to conduct lifestyles different from those of their parents. Intensifying investments in human capital is one of the future priorities of national public policy (Renato Miguel Carmo and Ana Rita Matias, 2018).

\subsubsection{Educational Inequalities Are Legitimate if They Are Linked to a Person's Level of Ability and Effort}

The class structure reproduces itself through the transmission of economic, social, and cultural capital from parents to their children. Students are differently equipped for educational careers respective to their social origin (Sophie Hahn, 2016). The focus on working-class educational pathways to university degrees reveals the huge variety of life histories that the working-class paths are longer and stonier (Antonia Kupfer, 2015). A learning society would enable all of its citizens, in particular those who are socially excluded, to have the capacity to meet the challenge of change (John Field, 2015). In a meritocratic perspective, educational inequalities are legitimate if they are linked to a person's level of ability and effort. Accordingly, more talented individuals who make efforts should reach higher levels of education and, higher occupational and social positions (Sophie Hahn, 2016).

\subsubsection{Social Problems Could be Alleviated by Transforming into Problems of Quality}

Alongside the policy initiatives, such as the expansion of higher education and raising the age of compulsory participation in education, these measures are underpinned by the view that social problems such as unemployment, poverty and social inequality could be alleviated by transforming them into problems of educational access and quality (Robin Simmons, Ron Thompson and Lisa Russell, 2014). As universities struggle to meet their society's changing demands, they are changing their patterns of provision to accommodate more friendly approaches, such as part-time study, various forms of open and distance education. In addition, they are exploring their role in several areas of adult education: challenging social exclusion, and advancing participation and social justice (Tom Nesbit, 2015 ).

\subsubsection{Equalising of Educational Opportunity Lie in the Reduced Tolerance for Social Hierarchy}

We should seek to revise the measures of institutional quality, in particular by exploring the concepts of inclusive excellence, equity and diversity that provide students with the high quality learning experience. The national equity framework could refocus from fairness to equity, and from some students to all (Andrew Harvey, Catherine Burnheim , and Matthew Brett, 2016). If "A Fair Chance for All" can be seen as an important precursor to policies focused on educational equity, higher education is no longer an institution for an elite few (Sam Sellar and Trevor Gale, 2016). If there is to be a new equalising of educational opportunity, the preconditions lie in the reduced tolerance for social hierarchy (Simon Marginson, 2016A). Moreover, the participation rates of students reflect a focus on ensuring equality of opportunity. The rise of female participation in higher education remains the notable student equity success. However, this compositional change owes much to the structural and societal reforms (Andrew Harvey, Catherine Burnheim, and Matthew Brett, 2016).

\subsection{Limitations and Implications}

\subsubsection{Higher Education Becomes Responsible not Just For Social Justice but Economic Growth}

The future of local communities lies within their ability to compete in a global market where economies realize the importance of intellectual capacity to meet the challenges of change and uncertainty. The development of a flexible and multi-skilled workforce has implications for education (Christina Hajisoteriou and Panayiotis Angelides, 2016). Higher education has a responsibility to keep students informed of labour market risks and opportunities (Cheryl A. Matherly and Martin J. Tillman, 2015). The idea of education for human capital assurances that the young are getting the skills presumed to make them successful in the workplace (Theodora Lightfoot-Rueda and Ruth Lynn Peach, 2015). The government should combine excellence and equality and should build education systems to provide for opportunity. Higher education becomes responsible not just for personal development and social justice, but economic growth (Simon Marginson, 2016A. Despite the expansion of the educational systems, there has been little change in socioeconomic inequality of educational opportunity (Ottar Hellevik, 2013). Governments should realize how important it is for the interpretation that a rising level of education in the population, has produced a steady reduction in the degree of inequality in the distribution of higher education across classes.

\subsubsection{Increasing Educational Opportunities Brings Benefits to Society}

Increasing educational opportunities brings benefits to the whole of society, and educational achievement is a central factor in individual social mobility. The unemployed young was replaced with a more problematic figure, the young person outside education and employment (Robin Simmons, Ron Thompson and Lisa Russell, 2014). Recent reforms in secondary schools have placed the spotlight on TVET, with the aim of raising retention to achieve year 12 qualifications, as well as delivering effective training to meet the skills needed by industry. However, the main users of TVET continue 
to be low achievers and socioeconomically disadvantaged students (Daniele Morselli, 2015; Lin Mei-Ling, 2019). A consequence of this can be seen in the progressive transformation of the welfare states into workfare or learnfare states (Daniele Morselli, 2015). Getting people to face challenges and uncertainty in the world of work with entrepreneurial spirit will promote the Taiwan economy to respond to challenges and adapt to change. The government should realize how important it is for the economic growth and social progress to motivate individuals to seize and develop opportunities.

\subsubsection{Examine Whether Educational Expansion Led to Social Fluidity}

This study can be read as a special account in the process of social change by demonstrating how structural changes enable the students to seek higher education, to change class, and to conduct lifestyles different from those of their parents (Antonia Kupfer, 2015). This analysis has some limitations, because, due to the low number of cases ( $\mathrm{N}=236$ ), and cohorts cover a considerable proportion of the group of persons with sex are female (74.6\%). Through a statistical analysis, the data shows their relationship with other forms of social vulnerability such as poverty, unemployment and precariousness. Given the complexity of inequalities, many questions remain about both the causes and consequences of stratification, and theory and research on inequalities will continue to be central to the discipline of sociology (Katja M. Guenther, Matthew C. Mahutga , and Panu Suppatkul, 2016). It is interesting to disentangle the mediated effects of social origin to examine whether educational expansion has led to more social fluidity (Sophie Hahn, 2016). A national strategy for social cohesion must be accomplished through higher (adult) education. Thus lifelong learning should be recognized as a key strategy in building a national safety net and in increasing social investment. The future will call for creative humans, so flexible higher (adult) education systems need to be established to foster a learning environment. Therefore greater participation in higher vocational education are needed (In Tak Kwon, 2015). We should heightens the significance of higher (adult) education as an economic policy tool, because education and training are seen to play a crucial role in maintaining national competitiveness (Richard Desjardins, 2018). Issues, such as "May these socioeconomic indicators have divergent effects on lifestyles and social stratification from higher (adult) education?", "How about the relationship of the OED triangle: social origin $(\mathrm{O})$ affects educational attainment $(\mathrm{E})$, and the latter affects the social destination (D)", and "Could the impact of educational reforms on changes in educational stratification be negligible?", and so on, are deserved us to study.

\section{References}

Anastasia, L. (2015). Inclusive Education and the Issue of Change. Theory, Policy and Pedagogy. Palgrave Macmillan. ISBN 9781349673599 ISBN 9781137333704 (eBook).

Andrew, H., Catherine, B., \& Matthew, B. (2016). Towards a Fairer Chance for All: Revising the Australian Student Equity Framework. In Andrew, H., Matthew, B., \& Catherine, B. (Eds.), Student Equity in Australian Higher Education. Twenty-five years of A Fair Chance for All (3-20). Springer Singapore Heidelberg New York Dordrecht London. ISBN 9789811003134 ISBN 9789811003158 (eBook). https://doi.org/10.1007/978-981-10-0315-8_1

Andrew, S. (2013). Facing the Challenge of the Return of the Rich. In Will, A., Steven, R., \& Mike, S. (Eds.), Class Inequality in Austerity Britain. Power, Difference and Suffering (163-179). Palgrave Macmillan. ISBN 9781349437016 ISBN 9781137016386 (eBook). https://doi.org/10.1057/9781137016386_10

Ann-Marie, B., Nicola, I., Jessie, A., Anthony, H., Richard, W., \& Harriet, B. (2016). Higher Education, Social Class and Social Mobility. The Degree Generation. Palgrave Macmillan. ISBN 9781137534804 ISBN 9781137534811 (eBook).

Antonia, K. (2015). Educational Upward Mobility. Practices of Social Changes. Palgrave Macmillan. ISBN 9781349470082 ISBN 9781137355317 (eBook).

António, F. da C., Rosário, M., Susana, da C. M., Nuno, N., \& Ana, L. R. (2018). Distributional and Categorical Inequalities in Europe: Structural Configurations. In Renato, M. C., Cédric, R., \& Márton, M. (Eds.), Reducing Inequalities. A Challenge for the European Union? (63-74). Palgrave Macmillan. ISBN 9783319650050 ISBN 9783319650067 (eBook). https://doi.org/10.1007/978-3-319-65006-7_5

Carl le, G., \& Michael, T. (2013). Class, Occupation, Wages, and Skills: The Iron Law of Labor Market Inequality. In Gunn, E. B. (Eds.), Class and Stratification Analysis (3-46). Palgrave Macmillan. ISBN: 9781781905371 eISBN: 978178195388. https://doi.org/10.1108/S0195-6310(2013)0000030006

Cheryl, A. M., \& Martin, J. T. (2015). Higher Education and the Employability Agenda. In Jeroen, H., Harry, de B., David, D. D., \& Manuel, S. O. (Eds.), The Palgrave International Handbook of Higher Education Policy and Governance (281-299). Palgrave Macmillan. ISBN 9781349577095 ISBN 9781137456175 (eBook). https://doi.org/10.1007/978-1-137-45617-5_16 
Christina, H., \& Panayiotis, A. (2016). The Globalisation of Intercultural Education. The Politics of Macro-Micro Integration. Palgrave Macmillan. ISBN 9781137522986 ISBN 9781137522993 (eBook).

Daniele, M. (2015). Enterprise Education in Vocational Education. A Comparative Study Between Italy and Australia. Palgrave Macmillan. ISBN 9781349559701 ISBN 9781137552617 (eBook).

David, P. (2010). Postsecondary Educational Expansion and Social Intergration in Hong Kong. In Emily, H., Hyunjoon, P., Yuko, G. B. (Eds.), Globalization, Changing Demographics, and Educational Challenges in East Asia. Research in Sociology of Education, Vol. 17 (231-269). Emerald Group Publishing Limited. ISBN: 9781849509763 eISBN: 9781849509770.

Diane, R. (2013). 'We never get a fair chance': Working-Class Experiences of Education in the Twenty-First Century. In Will, A., Steven, R., \& Mike, S. (Eds.), Class Inequality in Austerity Britain. Power, Difference and Suffering (33-50). Palgrave Macmillan. ISBN 9781349437016 ISBN 9781137016386 (eBook). https://doi.org/10.1057/9781137016386_3

Emmaline, B. (2016). Further and Higher? Institutional Diversity and Stratification. In Andrew, H., Matthew, B., \& Catherine, B. (Eds.), Student Equity in Australian Higher Education. Twenty-five years of A Fair Chance for All (275-292). Springer Singapore Heidelberg New York Dordrecht London. ISBN 9789811003134 ISBN 9789811003158 (eBook).

Emmanuel, J. F. (2015). Building Global Education with a Local Perspective. An Introduction to Glocal Higher Education. Palgrave Macmillan. ISBN 9781349483075 ISBN 9781137386779 (eBook).

Eugenia, A. P. (2015). Towards 'Utilitarian' Adult Education Perspectives? A Critical Review of the European Union's Adult Education Policy. In Marcella, M., \& Tom, N. (Eds.), Global Perspectives on Adult Education and Learning Policy (207-220). Palgrave Macmillan. ISBN 9781349561995 ISBN 9781137388254 (eBook). https://doi.org/10.1057/9781137388254_15

Francisco, O. R., John, W. M., \& Julia, L. (2016). World Society and the Globalization of Educational Policy. In Karen, M., Andy, G., Bob, L., \& Antoni, V. (Eds.), The Handbook of Global Education Policy (43-63). John Wiley \& Sons, Ltd. ISBN 9781118468036 (Adobe PDF) | ISBN 9781118468043 (ePub).

Frederick, H. P. (2018). Creative Labour, Before and After 'Going Freelance': Contextual Factors and Coalition-Building Practices. In Stephanie, T., \& Susan, L. (Eds.), The New Normal of Working Lives. Critical Studies in Contemporary Work and Employment (87-108). Palgrave Macmillan. ISBN 9783319660370 ISBN 9783319660387 (eBook). https://doi.org/10.1007/978-3-319-66038-7_5

Gartman, D. (2013). Culture, class, and critical theory [electronic resource]: between Bourdieu and the Frankfurt school. New York: Routledge. https://doi.org/10.4324/9780203080818

Gary, N. M. (2013). Reproduction of Economic Inequalities: Are the Figures for the United States and United Kingdom Too High? In Gunn, E. B. (Eds.), Class and Stratification Analysis (341-363). Palgrave Macmillan. ISBN: 9781781905371 eISBN: 978178195388 . https://doi.org/10.1108/S0195-6310(2013)0000030016

Gianluca, M. (2013). Educational Choices and Social Interactions: A Formal Model and a Computational Test. In Gunn, E. B. (Eds.), Class and Stratification Analysis (47-100). Palgrave Macmillan. ISBN: 9781781905371 eISBN: 978178195388. https://doi.org/10.1108/S0195-6310(2013)0000030007

Guillaume, C., \& Maxime, L. (2018). Drivers of Growing Income Inequalities in OECD and European Countries. In Renato, M. C., Cédric, R., \& Márton, M. (Eds.), Reducing Inequalities. A Challenge for the European Union? (31-44). Palgrave Macmillan. ISBN $9783319650050 \quad$ ISBN 9783319650067 (eBook). https://doi.org/10.1007/978-3-319-65006-7_3

Gunn, E. B. (2013). Introduction. In Gunn, E. B. (Ed.), Class and Stratification Analysis (xv- xx). Palgrave Macmillan. ISBN: 9781781905371 eISBN: 978178195388 . https://doi.org/10.1108/S0195-6310(2013)0000030005

Gunn, E. B., \& Yannick, L. (2013). Lifestyles and Social Stratification: An Explorative Study of France and Norway. In Gunn, E. B. (Ed.), Class and Stratification Analysis (189-220). Palgrave Macmillan. ISBN: 9781781905371 eISBN: 978178195388. https://doi.org/10.1108/S0195-6310(2013)0000030011

Hanna-Mari, I. (2018). Letting Them Get Close: Entrepreneurial Work and the New Normal. In Stephanie, T., \& Susan, L. (Eds.), The New Normal of Working Lives. Critical Studies in Contemporary Work and Employment (265-284). Palgrave Macmillan. ISBN 9783319660370 ISBN 9783319660387 (eBook). https://doi.org/10.1007/978-3-319-66038-7_13

Harriet, B., \& Nicola, I. (2013). Banking on the Future: Choices, Aspirations and Economic Hardship in Working-Class 
Student Experience. In Will, A., Steven, R., \& Mike, S. (Eds.), Class Inequality in Austerity Britain. Power, Difference and Suffering (51-69). Palgrave Macmillan. ISBN 9781349437016 ISBN 9781137016386 (eBook). https://doi.org/10.1057/9781137016386_4

In Tak, K. (2015). Towards a Learning Society: An Analysis of Adult Education Policies and Systems in South Korea. In Marcella, M., \& Tom, N. (Eds.), Global Perspectives on Adult Education and Learning Policy (132-147). Palgrave Macmillan. ISBN 9781349561995 ISBN 9781137388254 (eBook). https://doi.org/10.1057/9781137388254_10

John, F. (2015). Policies for Adult Learning in Scotland. In Marcella Milana and Tom Nesbit (Eds.), Global Perspectives on Adult Education and Learning Policy (15-28). Palgrave Macmillan. ISBN 9781349561995 ISBN 9781137388254 (eBook). https://doi.org/10.1057/9781137388254_2

John, M. A. (2015). The New Class in Post-Industrial Society. Palgrave Macmillan. ISBN 9781349576630 ISBN 9781137515414 (eBook).

Karen, M., Andy, G., Bob, L., \& Antoni, V. (2016). Introduction: The Globalization of Education Policy - Key Approaches and Debates. In Karen, M., Andy, G., Bob, L., \& Antoni, V. (Eds.), The Handbook of Global Education Policy (1-20). John Wiley \& Sons, Ltd. ISBN 9781118468036 (Adobe PDF) | ISBN 9781118468043 (ePub).

Katja, M. G., Matthew, C. M., \& Panu, S. (2016). Stratification. In Seth, A. (Ed.), Handbook of Contemporary Sociological Theory (229-246). Springer International Publishing Switzerland. ISBN 9783319322483 (HB) ISBN 9783319322506 (eBook).

Lin, M. L. (2019). Challenges and Opportunities for Technical and Vocational Education and Training in the local communities: Education and Labour Market for Young People. International Journal of Social Science Studies, 7(3). https://doi.org/10.11114/ijsss.v7i3.4136

Liza, R. (2013). From Abstract to Concrete: The Practical Relevance of Parents Economic and Cultural Capital for Persistence in Higher Education. In Gunn, E. B. (Ed.), Class and Stratification Analysis (223-254). Palgrave Macmillan. ISBN: 9781781905371 eISBN: 978178195388 . https://doi.org/10.1108/S0195-6310(2013)0000030012

Lyn, T. (2018). Participation in Adult Literacy Programmes and Social Injustices. In Marcella, M., Sue, W., John, H., Richard, W., \& Peter, J. (Eds.), The Palgrave International Handbook on Adult and Lifelong Education and Learning (359-374). Palgrave Macmillan. ISBN 9781137557827 ISBN 9781137557834 (eBook). https://doi.org/10.1057/978-1-137-55783-4_19

Martin, C. (2016). Educational Policies in the Face of Globalization: Whither the Nation State? In Karen, M., Andy, G., Bob, L., \& Antoni, V. (Eds.), The Handbook of Global Education Policy (27-42). John Wiley \& Sons, Ltd. ISBN 9781118468036 (Adobe PDF) | ISBN 9781118468043 (ePub).

Márton, M. (2018). Inequality of Outcomes and Opportunities Among the Young. In Renato, M. Ca., Cédric, R., \& Má rton, M. (Eds.), Reducing Inequalities. A Challenge for the European Union? (115-134). Palgrave Macmillan. ISBN 9783319650050 ISBN 9783319650067 (eBook). https://doi.org/10.1007/978-3-319-65006-7_8

Michael, D. (2018). Disposable Income Inequality, Cohesion and Crisis in Europe. In Renato, M. C., Cédric, R., \& Má rton, M. (Eds.), Reducing Inequalities. A Challenge for the European Union? (13-30). Palgrave Macmillan. ISBN 9783319650050 ISBN 9783319650067 (eBook). https://doi.org/10.1007/978-3-319-65006-7_2

Orsolya, L., \& Katrin, G. (2018). Income Poverty in the EU: What Do We Actually Measure? Empirical Evidence on Choices, Underlying Assumptions and Implications (Based on EU-SILC 2005 - 2014). In Renato, M. C., Cédric, R., \& Márton, M. (Eds.), Reducing Inequalities. A Challenge for the European Union? (75-96). The Author(s). This Palgrave Macmillan imprint is published by Springer Nature. ISBN 9783319650050 ISBN 9783319650067 (eBook). https://doi.org/10.1007/978-3-319-65006-7_6

Ottar, H. (2013). Measuring Social Inequality In Educational Attainment. In Gunn, E. B. (Ed.), Class and Stratification Analysis (319-339). Palgrave Macmillan. ISBN: 9781781905371 eISBN: 978178195388. https://doi.org/10.1108/S0195-6310(2013)0000030015

Pasi, S. (2016). The Global Educational Reform Movement and Its Impact on Schooling. In Karen, M., Andy, G., Bob, L., \& Antoni, V. (Eds.), The Handbook of Global Education Policy (128-144). John Wiley \& Sons, Ltd. ISBN 9781118468036 (Adobe PDF) | ISBN 9781118468043 (ePub).

Penny, J. B., \& Yu-Ching, K. (2015). Widening Participation in Higher Education: Policy Regimes and Globalizing Discourses. In Jeroen, H., Harry, de B., David, D. D., \& Manuel, S. O. (Eds.), The Palgrave International 
Handbook of Higher Education Policy and Governance (547-568). Palgrave Macmillan. ISBN 9781349577095 ISBN 9781137456175 (eBook). https://doi.org/10.1007/978-1-137-45617-5_29

Rajarshi, M. (2013). Intergenerational Mobility. A Study of Social Classes in India. Springer New Delhi Heidelberg New York Dordrecht London. ISBN 9788132211297 ISBN 9788132211303 (eBook).

Renato, M. C., \&Ana, R. M. (2018). Unemployment, Precariousness and Poverty as Drivers of Social Inequality: The Case of the Southern European Countries. In Renato, M. C., Cédric, R., \& Márton, M. (Eds.), Reducing Inequalities. A Challenge for the European Union? (45-62). The Author(s). This Palgrave Macmillan imprint is published by Springer Nature. ISBN 9783319650050 ISBN 9783319650067 (eBook). https://doi.org/10.1007/978-3-319-65006-7_4

Renato, M. C., Cédric, R., \& Márton, M. (2018). Introduction. In Renato, M. C., Cédric, R., \& Márton, M. (Eds.), Reducing Inequalities. A Challenge for the European Union? (1-10). The Author(s). This Palgrave Macmillan imprint is published by Springer Nature. ISBN 9783319650050 ISBN 9783319650067 (eBook). https://doi.org/10.1007/978-3-319-65006-7_1

Richard, D. (2018). Economics and the Political Economy of Adult Education. In Marcella, M., Sue, W., John, H., Richard, W., \& Peter, J. (Eds.), The Palgrave International Handbook on Adult and Lifelong Education and Learning (211-226). Palgrave Macmillan. ISBN 9781137557827 ISBN 9781137557834 (eBook). https://doi.org/10.1057/978-1-137-55783-4_12

Robin, R. M., \& Ruth, U. O. (2018). Global Migration of Talent: Drain, Gain, and Transnational Impacts. In Joan, R. D., Robin, R. M., \& Matt, M. (Eds.), International Scholarships in Higher Education. Pathways to Social Change (209-234). Palgrave Macmillan. ISBN 9783319627335 ISBN 9783319627342 (eBook). https://doi.org/10.1007/978-3-319-62734-2_11

Robin, S., Ron, T., \& Lisa, R. (2014). Education, Work and Social Change. Young People and Marginalization in Post-Industrial Britain. Palgrave Macmillan. ISBN 9781137335937 ISBN 9781137335944 (eBook).

Rómulo, P., Gerald, W. O., Elizabeth, B., \& Cai, Y. Z. (2015). The Role of Higher Education in Society and the Changing Institutionalized Features in Higher Education. In Jeroen, H., Harry, de B., David, D. D., \& Manuel, S. O. (Eds.), The Palgrave International Handbook of Higher Education Policy and Governance (225-243). Palgrave Macmillan. ISBN 9781349577095 ISBN 9781137456175 (eBook).

Sam, S., \& Trevor, G. (2016). Framing Student Equity in Higher Education: National and Global Policy Contexts of A Fair Chance for All. In Andrew, H., Matthew, B., \& Catherine, B. (Eds.), Student Equity in Australian Higher Education. Twenty-five years of A Fair Chance for All (39-52). Springer Singapore Heidelberg New York Dordrecht London. ISBN 9789811003134 ISBN 9789811003158 (eBook). https://doi.org/10.1007/978-981-10-0315-8_3

Simon, M. (2016A). Higher Education and Inequality in Anglo- American Societies. In Andrew, H., Matthew, B., \& Catherine, B. (Eds.), Student Equity in Australian Higher Education. Twenty-five years of A Fair Chance for All (165-182). Springer Singapore Heidelberg New York Dordrecht London. ISBN 9789811003134 ISBN 9789811003158 (eBook).

Simon, M. (2016B). The Global Construction of Higher Education Reform. In Karen, M., Andy, G., Bob, L., \& Antoni, V. (Eds.), The Handbook of Global Education Policy (291-312). John Wiley \& Sons, Ltd. ISBN 9781118468036 (Adobe PDF) | ISBN 9781118468043 (ePub).

Soo-yong, B., \& Kyung-keun, K. (2010). Educational Inequality in South Korea: The Widening Socioeconomic Gap in Student Achievement. In Emily, H., Hyunjoon, P., \& Yuko, G. B. (Eds.), Globalization, Changing Demographics, and Educational Challenges in East Asia. Research in Sociology of Education, Vol.17 (155-182). Emerald Group Publishing Limited. ISBN: 9781849509763 eISBN: 9781849509770.

Sophie, H. (2016). The Risk of Downward Mobility in Educational Attainment, Life Course Research. Children of Higher-Educated Parents in Germany. Springer Fachmedien Wiesbaden. ISBN 9783658145972 ISBN 9783658145989 (eBook).

Steffen, H. (2013). Analysing Intergenerational Transmissions: From Social Mobility to Social Reproduction. In Gunn Elisabeth Birkelund (Ed.), Class and Stratification Analysis (131-157). Palgrave Macmillan. ISBN: 9781781905371 eISBN: 978178195388. https://doi.org/10.1108/S0195-6310(2013)0000030009

Stephanie, T. (2018). Beyond Work? New Expectations and Aspirations. In Stephanie, T., \& Susan, L. (Eds.), The New Normal of Working Lives. Critical Studies in Contemporary Work and Employment (327-346). Palgrave Macmillan. ISBN 9783319660370 ISBN 9783319660387 (eBook). https://doi.org/10.1007/978-3-319-66038-7_16 
Stephanie, T., \& Susan, L. (2018). Collection Introduction: The 'New Norma' of Working Lives. In Stephanie, T., \& Susan, L. (Eds.), The New Normal of Working Lives. Critical Studies in Contemporary Work and Employment (1-16). Palgrave Macmillan. ISBN $9783319660370 \quad$ ISBN $9783319660387 \quad$ (eBook). https://doi.org/10.1007/978-3-319-66038-7_1

Stephen, K., \& Christine, E. G. (2018). Understanding Education. History, Politics and Practice. Springer Nature Singapore Pte Ltd. ISBN 9789811064326 ISBN 9789811064333 (eBook).

Steven, R., \& Sarah, E. (2013). 'Aspirations' and Imagined Futures: The Im/possibilities for Britain's Young Working Class. In Will, A., Steven, R., \& Mike, S. (Eds.), Class Inequality in Austerity Britain. Power, Difference and Suffering (70-89). Palgrave Macmillan. ISBN 9781349437016 ISBN 9781137016386 (eBook). https://doi.org/10.1057/9781137016386_5

Theodora, L. R., \& Ruth, L. P. (2015). Introduction and Historical Perspective. In Theodora, L. R., \& Ruth, L. P. (Eds.), Global Perspectives on Human Capital in Early Childhood Education. Reconceptualizing Theory, Policy, and Practice (3-26). Palgrave Macmillan. ISBN 9781349562015 ISBN 9781137490865 (eBook). https://doi.org/10.1057/9781137490865_1

Tom, N. (2015). Conclusion: Global Developments in Adult Education Policy. In Marcella, M., \& Tom, N. (Eds.), Global Perspectives on Adult Education and Learning Policy (237-251). Palgrave Macmillan. ISBN 9781349561995 ISBN 9781137388254 (eBook). https://doi.org/10.1057/9781137388254_17

Val, G. (2013). Personalising Poverty: Parental Determinism and the Big Society Agenda. In Will, A., Steven, R., \& Mike, S. (Eds.), Class Inequality in Austerity Britain. Power, Difference and Suffering (90-110). Palgrave Macmillan. ISBN 9781349437016 ISBN 9781137016386 (eBook). https://doi.org/10.1057/9781137016386_6

Will, A., Steven, R., \& Mike, S. (2013). Introduction: A Critical Sociology of the Age of Austerity. In Will, A., Steven, R., \& Mike, S. (Eds.), Class Inequality in Austerity Britain. Power, Difference and Suffering (1-12). Palgrave Macmillan. ISBN 9781349437016 ISBN 9781137016386 (eBook). https://doi.org/10.1057/9781137016386_1

Xavier, B. (2016). Education, Poverty, and the "Missing Link": The Limits of Human Capital Theory as a Paradigm for Poverty Reduction. In Karen Mundy, Andy Green, Bob Lingard, and Antoni Verger (Eds.), The Handbook of Global Education Policy (97-110). John Wiley \& Sons, Ltd. ISBN 9781118468036 (Adobe PDF) | ISBN 9781118468043 (ePub). https://doi.org/10.1002/9781118468005.ch5

\section{Copyrights}

Copyright for this article is retained by the author(s), with first publication rights granted to the journal.

This is an open-access article distributed under the terms and conditions of the Creative Commons Attribution license which permits unrestricted use, distribution, and reproduction in any medium, provided the original work is properly cited. 